SANDIA REPORT

SAND2006-0947

Unlimited Release

March 2006

$$
\begin{aligned}
& \text { DT\# } 47081 \\
& \text { QA:NA } \\
& 3 / 13 / 2006
\end{aligned}
$$

\title{
Workshop on Development of Radionuclide Getters for the Yucca Mountain Waste Repository: Proceedings
}

Conference Organizers:

Wayne W. Lukens, Lawrence Berkeley National Laboratory

Robert C. Moore, Sandia National Laboratories

Compiled by:

Kathleen C. Holt, Sandia National Laboratories

Prepared by

Sandia National Laboratories

Albuquerque, New Mexico 87185 and Livermore, California 94550

Sandia is a multiprogram laboratory operated by Sandia Corporation,

a Lockheed Martin Company, for the United States Department of Energy's

National Nuclear Security Administration under Contract DE-AC04-94AL85000.

Approved for public release; further dissemination unlimited. 
Issued by Sandia National Laboratories, operated for the United States Department of Energy by Sandia Corporation.

NOTICE: This report was prepared as an account of work sponsored by an agency of the United States Government. Neither the United States Government, nor any agency thereof, nor any of their employees, nor any of their contractors, subcontractors, or their employees, make any warranty, express or implied, or assume any legal liability or responsibility for the accuracy, completeness, or usefulness of any information, apparatus, product, or process disclosed, or represent that its use would not infringe privately owned rights. Reference herein to any specific commercial product, process, or service by trade name, trademark, manufacturer, or otherwise, does not necessarily constitute or imply its endorsement, recommendation, or favoring by the United States Government, any agency thereof, or any of their contractors or subcontractors. The views and opinions expressed herein do not necessarily state or reflect those of the United States Government, any agency thereof, or any of their contractors.

Printed in the United States of America. This report has been reproduced directly from the best available copy.

Available to DOE and DOE contractors from

U.S. Department of Energy

Office of Scientific and Technical Information

P.O. Box 62

Oak Ridge, TN 37831

Telephone:

(865)576-8401

Facsimile:

(865)576-5728

E-Mail:

Online ordering:

reports@adonis.osti.gov

http://www.doe.gov/bridge

Available to the public from

U.S. Department of Commerce

National Technical Information Service

5285 Port Royal Rd

Springfield, VA 22161

Telephone:

Facsimile:

E-Mail:

Online order:
(800)553-6847

(703)605-6900

orders@ntis.fedworld.gov

http://www.ntis.gov/help/ordermethods.asp?loc=7-4-0\#online 


\section{EXECUTIVE SUMMARY}

The proposed Yucca Mountain repository, located in southern Nevada, is to be the first facility for permanent disposal of spent reactor fuel and high-level radioactive waste in the United States. Total Systems Performance Assessment (TSPA) analysis has indicated that among the major radionuclides contributing to dose are technetium, iodine, and neptunium, all of which are highly mobile in the environment. Containment of these radionuclides within the repository is a priority for the Yucca Mountain Project (YMP).

These proceedings review current research and technology efforts for sequestration of the radionuclides with a focus on technetium, iodine, and neptunium. This workshop also covered issues concerning the Yucca Mountain environment and getter characteristics required for potential placement into the repository. 


\section{TABLE OF CONTENTS}

Executive Summary $\quad 3$

Introduction $\quad 6$

Conference Summary 7

SECTION I: Yucca Mountain Environment 11

1 Overview of the Yucca Mountain Total System Performance Assessment 12 Peter Swift

2 Chemistry Inside the Package at Yucca Mountain 14

Pat Brady

3. In Drift Flow

Eric Sonnenthal

SECTION II: Traditional Getter Materials $\quad 20$

4 Getters for Neptunium/Neptunium Sorption 21

Ken Nash

5 Iodine Chemistry and Potential Iodine Getters 24

J. Clara Wren

6 Traditional Getters for Technetium 27

Brian Viani

7 Development of Selective Ion Exchange and Carbon-Based Getters for 28

Pertechnetate Sorption

Baohua Gu

SECTION III: Nanoporous Materials

8 Strategic Design of Sorbents for Cesium, Strontium, and Actinide Removal from 30

Nuclear Waste Systems

Abraham Clearfield

9 Nanoporous Ti \& Zr Phosphate Getter Materials 33

Glen Fryxell

10 A Porous Glass 'Getter' for Long-lived Radionuclides : 35

Werner Lutze

11 Metal Doped Carbonaceous Materials for Sequestration of Anionic Fission 38

Products (Tc-99 and I-129)

Steven Serkiz

SECTION IV: Getter Durability $\quad 39$

12 Radiolytic Stability 40

Bill Weber

13 Geochemical Stability. 42

Susan Brantley

SECTION V: Thermodynamics and Modeling 43

14 Technetium Thermodynamics and Speciation 44

Joseph Rard 
APPENDICES

A Conference Attendees

B Workshop Agenda

49

C List of Publications Related to Radiation Effects on Potential "Getter" Materials 


\section{INTRODUCTION}

One of the important that the U.S. Department of Energy (DOE) is currently undertaking is the development of a high-level nuclear waste repository to be located at Yucca Mountain, Nevada. Concern is generated by the Yucca Mountain Project (YMP) is due to potential releases as groundwater contamination, as described in the Total System Performance Assessment (TSPA). The dose to an off-site individual using this groundwater for drinking and irrigation is dominated by four radionuclides: Tc-99, I-127, Np-237, and U-238. Ideally, this dose would be limited to a single radionuclide, U-238; in other words, YMP would resemble a uranium ore body, a common geologic feature in the Western U.S. For this reason and because of uncertainties in the behavior of Tc-99, I-127, and Np-237, it would be helpful to limit the amount of Tc, I, and Np leaving the repository, which would greatly increase the confidence in the long-term performance of YMP.

An approach to limiting the migration of $\mathrm{Tc}, \mathrm{I}$, and $\mathrm{Np}$ that is complementary to the existing YMP repository design plans is to employ sequestering agents or "getters" for these radionuclides such that their migration is greatly hindered, thus decreasing the amount of radionuclide leaving the repository. Development of such getters presents a number of significant challenges. The getter must have a high affinity and high selectivity for the radionuclide in question since there is approximately a 20 - to 50-fold excess of other fission products and a 1000-fold excess of uranium in addition to the ions present in the groundwater. An even greater challenge is that the getters must function over a period greater than the half-life of the radionuclide (greater than 5 half-lives would be ideal).

Typically, materials with a high affinity for $\mathrm{Tc}$, I, or $\mathrm{Np}$ are not sufficiently durable. For example, strong-base ion exchange resins have a very high affinity for $\mathrm{TcO}_{4}{ }^{-}$but are not expected to be durable. On the other hand, durable materials, such as hydrotalcite, do not have sufficient affinity to be useful getters. Despite these problems, the great increase in the repository performance and corresponding decrease in uncertainty promised by a useful getter has generated significant interest in these materials. This report is the result a workshop sponsored by the Office of Civilian Radioactive Waste Management and Office of Science and Technology and International of the DOE to assess the state of research in this field. 


\section{CONFERENCE SUMmary}

\section{Source Term}

There are a number of unknowns about the source term that could have an impact on the performance of getters. Foremost is uncertainty about the failure mode of the waste containers. It is not known whether the containers will corrode at a single site or multiple sites, and therefore what percentage of a getter placed in the invert will be in contact with water from the container. If leachate leaves the container at a single site, only a fraction of getter placed in the invert will be in contact with it. On the other hand, if the getter is placed within the container, there is a greater chance that the majority of the getter will be utilized. While this is obviously important for expensive getters (less would be used if the getter is placed within the container), it could also result in a greater amount of getter being in contact with the leachate. Whether this is the case depends upon how rapidly leached water diffuses laterally in an absorptive invert versus how quickly leachate flows downward through the invert.

Getter Performance: One of the major issues with employing getters is determining how well they would have to work to have an impact on the repository performance assessment. However, there are a number of ways to address this issue. Ideally, the getters would inhibit migration of the problem radionuclides to such a degree that the off-site dose is dominated by U-238. In practice, getters would be useful if they decrease leached radionuclide concentration by a factor of 10 , and a decrease by a factor of 100 would be ideal.

Another way to look at this issue is to examine the time needed for a radionuclide to pass through a sorptive invert, which has been tabulated in ANL-EBS-MD-000063, "Advection versus Diffusion in the Invert." If the invert has a $K_{d}$ of 100 , then breakthrough is delayed by $2 \times 10^{5}$ years, and if the invert has a $K_{d}$ of 1000 , breakthrough is delayed by $2 \times 10^{6}$ years, where $K_{d}=\frac{(g \text { of sorbed radionuclide })(m L \text { solution })}{(g \text { of radionclide in solution })(g \text { sorbent })}$.

In the case of a getter, the composition of the solution in which the $K_{d}$ is measured must reflect repository conditions to be relevant to getter performance. In other words, prior to measuring $\mathrm{K}_{\mathrm{d}}$, the getter must be in equilibrium with YMP pore water, and the solution used to determine $\mathrm{K}_{d}$ should have the same composition as pore water in contact with corroded stainless steel and spent fuel. Implicit in the desired $\mathrm{K}_{d}$ value is good selectivity for the radionuclide being adsorbed. In particular, $\mathrm{Np}$ getters need to have good selectivity for $\mathrm{Np}$ versus U. Tc getters need to have good selectivity for $\mathrm{TcO}_{4}{ }^{-}$versus other anions if they function via ion exchange, or Tc getters need to have good selectivity for $\mathrm{TcO}_{4}{ }^{-}$versus other electron acceptors (such as $\mathrm{O}_{2}$ ) if they function by reducing $\mathrm{TcO}_{4}{ }^{-}$to less soluble $\mathrm{Tc}(\mathrm{IV})$ species.

Durability: Although the requirements for the radionuclide affinity and selectivity of a useful getter material are not extreme, the durability requirements are. To be useful, a getter must function for several half-lives of the radionuclide being immobilized. During this time, it will be irradiated by the spent fuel. It will be exposed to temperatures approaching $200^{\circ} \mathrm{C}$ during the first 1000 years of emplacement, and finally the relative humidity within the drifts will be $\sim 100 \%$ for the lifetime of the repository. 
The resistance of getter materials to radiation can be determined using existing facilities to deliver the doses that the materials will receive over their lifetimes. Somewhat more difficult to determine is the effect of the recoil nucleus in the case of Np-237 getters. Similarly, the resistance of getters to the initial heat pulse of the repository should also be determined in a straightforward manner.

The geochemical stability of the getters over their useful life is much more difficult to ascertain. The most reliable method for determining such stability is examination of natural analogs. Where natural analogs are unavailable, geochemical modeling can be used. In either case, it should be noted that rates of dissolution or phase changes measured in the field are $\sim 10^{4}$ times slower than those measured in the laboratory. Finally, it should be noted that the affinity or selectivity of the getter could change over time, and this problem would have to be addressed.

\section{Speciation of radionuclides under repository conditions}

Technetium: Only one technetium species, $\mathrm{TcO}_{4}^{-}$, is highly mobile; however, this is the stable form of technetium under repository conditions. Preventing the migration of $\mathrm{TcO}_{4}^{-}$must be accomplished either by reduction to less soluble Tc(IV) or by sorption.

Iodine: The chemistry of iodine under repository conditions is complicated; several different species coexist in equilibrium. Because of rapid reequilibration, immobilization of any of these species is sufficient to immobilize iodine. The most easily immobilized species is iodide, which forms insoluble salts with several metal cations.

Neptunium: While the speciation of neptunium was not discussed at the workshop, it should be addressed. Both $\mathrm{Np}(\mathrm{V})$ and $\mathrm{Np}(\mathrm{IV})$ are stable under repository conditions. Although the redox potential is not reported at neutral $\mathrm{pH}$, it can be determined from the enthalpy of formation of the $\mathrm{Np}$ species present at a given $\mathrm{pH}$. The potential is similar to the Eh of pore water. Only $\mathrm{Np}(\mathrm{V})$ is particularly mobile; $\mathrm{Np}$ (IV) is relatively insoluble and is strongly adsorbed by mineral surfaces. A number of $\mathrm{Np}(\mathrm{V})$ species can exist under repository conditions: $\mathrm{NpO}_{2}{ }^{+}, \mathrm{NpO}_{2} \mathrm{OH}$, and $\mathrm{NpO}_{2}$ carbonate complexes. In all cases, the formation constants are relatively small. Preventing the migration of $\mathrm{Np}(\mathrm{V})$ either by sorption or by reduction to $\mathrm{Np}(\mathrm{IV})$ is sufficient to slow its migration. It should be noted that $\mathrm{Np}(\mathrm{IV})$ as well as $\mathrm{Tc}(\mathrm{IV})$ could still migrate if adsorbed on colloids.

\section{Survey of potential getter materials}

Silver metal/Silver salts: Silver metal and silver salts can immobilize iodide as insoluble AgI, and the chemistry is well understood. Although the enthalpy of formation of AgI is small, -16 $\mathrm{kcal} / \mathrm{mol}$, making AgI relatively easy to convert back into silver and iodine (the basis for photography), this reaction is clearly reversible since silver metal is a good sequestering agent for iodine and iodide.

The drawbacks for the use of silver as a getter are twofold. It is somewhat expensive $\left(\$ 177 \mathrm{~kg}^{-1}\right.$ as of $2 / 1 / 05$ ), but each container contains only $2 \mathrm{~kg}$ of $\mathrm{I}$, so the amount of silver needed would be small. The bigger drawback is that silver is a regulated toxic metal. Nevertheless, this was the only sequestering agent shown to have any effectiveness for I-127. Silver is also the single example of a getter material that has both high affinity for a radionuclide and is likely to be 
durable under repository conditions.

Layered Double Hydroxides: Layered double hydroxides (LDHs) are some of the very few oxide materials that exchange anions. They have good thermal stability, and the dehydrated form has very high affinity for anions. Many natural analogs exist. The main drawback to LDHs is selectivity: they generally have a much higher affinity for dianions, such as carbonate, than for monoanions, such as $\mathrm{TcO}_{4}^{-}$.

Carbon Materials: Carbon materials include carbon nanotubes and activated carbons, both modified and unmodified. Activated carbons are known to have very high affinity and selectivity for $\mathrm{TcO}_{4}{ }^{-}$even in the presence of a large excess of other anions, including nitrate. They have excellent thermal stability. Natural analogs exist (fusail, found in coal, is charcoal, one form of activated carbon). The resistance of these carbon materials to radiation is apparently not well known, but graphite has been well studied. The mechanism of immobilization of $\mathrm{TcO}_{4}{ }^{-}$ by carbon materials is not known for certain, but evidence strongly supports ion exchange rather than reduction to $\mathrm{Tc}(\mathrm{IV})$. Finally, activated carbon is fairly inexpensive ( $\sim 20$ per cu. $\mathrm{ft}$.).

The major drawback of carbon materials is that carbon is a good neutron moderator. To be usable, these materials could not adsorb uranium, or a neutron poison, such as gadolinium or boron, would have to be incorporated. For the same reason, carbon materials might be unsuitable for use inside waste containers.

Porous Glass: Porous glass has excellent durability characteristics. It is very stable to radiation and heat, and natural analogs exist, allowing its geochemical stability to be estimated. Porous glass is also relatively inexpensive.

The main drawback to porous glasses is that as initially prepared they do not adsorb these radionuclides. Rather, they are durable, high surface area materials that must be modified to immobilize radionuclides.

Microporous Materials: These materials include crystalline oxides such as zeolites or titanosilicates that could potentially be used to immobilize $\mathrm{Np}(\mathrm{V})$ by ion-exchange. Many of these materials, most notably zeolites, have excellent thermal and geochemical stability, and natural analogs are well known.

The main drawback to microporous materials is unknown selectivity. Although most zeolites are selective for dications, such as $\mathrm{Ca}^{2+}$, over monocations such as $\mathrm{Na}^{+}$, actual selectivity is a complicated function of structure and charge density in the aluminosilicates (or titanosilicate) framework. It should be noted that these materials can be tailored to have a high affinity for certain cations (such as the affinity of CST for $\mathrm{Cs}^{+}$), but this is generally not a straightforward process.

Mesoporous Materials: These materials are synthetic oxides with very high surface areas that can be functionalized. They can have very high affinity, selectivity, and capacity for contaminants. They are expensive, but the cost can be justified if the capacity is high since the cost per mole of immobilized radionuclide could be low. The completely inorganic materials 
have good thermal stability since they are generally prepared by calcination at elevated temperatures.

The main drawback to these materials is unknown geochemical durability. These are recently developed synthetic materials for which no natural analogs exist. Durability would have to be estimated using geochemical modeling.

Aerogels: Aerogels are high-surface area, high-pore volume materials that are usually composed of silica. Their surface chemistry is analogous to porous glasses or silica mesoporous materials; however, their mechanical stability is much worse: aerogels are brittle and fragile. Like porous glasses or silica mesoporous materials, their surfaces would have to be modified to allow them to function as getters.

Apatite: Apatite is well-known to have a high affinity for actinides. It is relatively inexpensive and is a naturally occurring mineral.

Apatite has two main drawbacks. It is slightly soluble and might not be sufficiently durable if placed in the invert (it could still be used inside a container). The second drawback is selectivity: apatite strongly adsorbs $\mathrm{U}(\mathrm{VI})$ and might not be able to immobilize $\mathrm{Np}(\mathrm{V})$ in the presence of the large excess of $\mathrm{U}(\mathrm{VI})$ that would exist under repository conditions.

Manganese Oxides: Manganese oxides are well known, and a large number of natural analogs exist. They tend to have a high affinity for cations. Their selectivity for the target radionuclide would have to be demonstrated. 


\section{SECTION I:}

\section{YucCa Mountain Environment}

\section{Page 11 of 55}




\section{Overview of the Yucca Mountain Total System Performance Assessment}

Peter Swift

Manager, Organization 06851

Total System Performance Assessment

Sandia National Laboratories MS 0778

Albuquerque, NM 87185-0778

\section{Email: pnswift@sandia.gov}

In the context of nuclear waste repository programs, performance assessment is the probabilistic risk assessment approach used to provide quantitative estimates of the behavior of the proposed disposal system in the far future. For Yucca Mountain performance assessment is specified in the applicable regulations of the United States Environmental Protection Agency (EPA, 40 CFR Part 197) and the United States Nuclear Regulatory Commission (NRC, 10 CFR Part 63) as the approach the Department of Energy (DOE) shall use to evaluate consequences associated with all significant features, events, and processes that could effect the future performance of the system. Radionuclide releases and radiation doses to a hypothetical individual shall be estimated for the next 10,000 years, considering uncertainty associated with those features, events, and processes and the probability of their occurrence. By regulation, the site may be licensed if the NRC finds a "reasonable expectation" that the mean performance, considering uncertainty, meets specified limits: specifically, the peak of estimated mean annual radiation doses during the next 10,000 years to a "reasonably maximally exposed individual" must be below 15 millirem. Additional limits apply to allowable concentrations of specific radionuclides in groundwater for a subset of release scenarios that does not include unlikely natural events.

The DOE identifies the performance assessment for Yucca Mountain as a "total system performance assessment" (TSPA) to emphasize that the analyses must evaluate overall performance of the full system rather than focusing on the performance of individual components of the system. The TSPA must contain quantitative models for processes associated with each of the major components of the system, and the TSPA must link these components together computationally to provide the system-level performance measures. Individual components are typically analyzed in detail experimentally (where appropriate) and through the use of mechanistic process models. Because of the complexity of the system and the need to perform multiple Monte-Carlo calculations to evaluate the effects of uncertainty in model inputs, these process models are typically simplified before incorporation in the TSPA, which relies on model abstractions that do not include full mechanistic detail but which do allow incorporation of the significant uncertainties associated with each process.

The DOE has completed multiple iterations of TSPA for Yucca Mountain in the last decade and is planning to support a License Application (LA) to the NRC (scheduled for December 2004) with a complete update of the TSPA. Results of the TSPA-LA are not available at this time, and all results discussed at this workshop will be drawn from past published TSPAs. With respect to possible roles for radionuclide getters, conclusions from these past TSPAs are robust and remain an appropriate starting point for discussion. 
Major components within the TSPA include models for each of the following: mountain-scale unsaturated zone flow, including climate change and infiltration; engineered barrier system thermal hydrology; drift seepage and drift-wall condensation; engineered barrier system chemical environment; waste package and drip-shield degradation; engineered barrier system flow; waste form degradation; engineered barrier system transport; unsaturated zone transport; saturated zone flow and transport; the biosphere; and processes associated with disruptive igneous and seismic events.

Results of past TSPAs indicate that potential radiation doses to future humans are dominated by two long-lived radionuclides: technetium-99 and neptunium-237. Technetium-99 is important in the Yucca Mountain system because of its extremely high solubility (it is treated in the TSPA as having effectively unlimited solubility, with concentrations controlled by the degradation rate of the waste form). High aqueous concentrations lead to relatively rapid, diffusive transport of technetium-99 away from the waste form, and it therefore becomes the major contributor to total dose in circumstances where engineered barriers prevent water flow and advective transport. Because of its relative abundance in the disposal system inventory and its moderately high solubility limits in the oxidizing repository environment, neptunium-237 is also a significant contributor to diffusive releases and is the dominant contributor to total dose in circumstances where advective transport is important. Such conditions occur, for example, at later times after the engineered barrier components of the drip shield and waste package have failed. Other radionuclides including iodine-129 and isotopes of plutonium, uranium, radium, and thorium could be more significant contributors to total dose if technetium-99 and neptunium-237 were more effectively retarded in their transport away from the waste form.

\section{Acknowledgements}

The Yucca Mountain Total System Performance Assessments have been performed by a team of scientists and engineers from Bechtel SAIC Company, LLC, Sandia National Laboratories, Framatome ANP, Intera, and other organizations. Sandia is a multiprogram laboratory operated by Sandia Corporation, a Lockheed Martin company, for the United States Department of Energy under contract DE-AC04-94AL85000. 


\section{Chemistry Inside the Package at Yucca Mountain}

Patrick V. Brady

Geochemistry Department

Sandia National Laboratories

PO Box 5800, MS-0750

Albuquerque, New Mexico 87185-0750

Email: pvbrady@sandia.gov

\section{Introduction}

If radioactive waste is ever to leave the proposed high-level waste repository at Yucca Mountain, Nevada oxygen must be present to corrode the fuel and convert radionuclides to their more mobile forms; water must be on hand to hasten fuel degradation and provide an exit path from the waste package. Both must first get past an outer, corrosion-resistant barrier made of Alloy 22 , then beyond an inner vessel of $5 \mathrm{~cm}$ thick 316 stainless steel-presumably through stress corrosion cracks in the first few thousand years and/or corrosion patches that form over much longer time spans.

Oxidizing conditions are expected to prevail at Yucca Mountain since the repository is in the unsaturated zone high above the water table. In oxidizing fluids, spent fuel releases radionuclides such as ${ }^{99} \mathrm{Tc}$ and ${ }^{237} \mathrm{~Np}$ quickly and in forms that are both soluble and less likely to sorb. In-package fluid pHs will likely be held to between 5 and 8 by the near neutral pH solubility of oxidized uranium minerals (e.g. schoepite) and by protonation and deprotonation reactions at ferric (hydr)oxide (rust) surfaces.

There is ample reason to expect reducing conditions inside the package. Note from Table 1 that the primary chemical feature of waste packages will be iron-roughly $2.3 \times 10^{5}$ moles total, nearly half of which will be present in A516 low carbon steel and half in 316 stainless steel. There will be almost 6 times as much iron in a 21 Pressurized Water Reactor (PWR) waste package as there will be uranium and roughly the same amount of $\mathrm{Cr}$ as $\mathrm{U}$. To oxidize the $\mathrm{U}$ in the waste package will require $3.9 \times 10^{4}$ moles of oxygen. The oxygen demand of the steels that will surround the fuel is ten times greater at $4.1 \times 10^{5}$ moles. The high oxygen demand of the steels, their relatively rapid degradation, and the potential for self-sealing by their corrosion products raises the possibility that steel degradation reactions might "starve" the underlying CSNF of oxygen and water and thereby prevent its degradation altogether (Stockman and LeStrange, 2003; Forsberg and Dole, 2003).

Roughly 70,000 metric tons of nuclear waste is to be stored at Yucca Mountain, and the bulk of it ( 80\% by weight) is commercial spent nuclear fuel (CSNF). US Department of Energy (DOE) spent nuclear fuel and high-level waste glass will make up the rest. Once the fuel decay heat has dissipated, long-term, in-drift temperatures will attenuate from boiling to $\sim 25^{\circ} \mathrm{C}$ in roughly 50,000 years. 
Table 1. Chemical characteristics of primary components in a 21 PWR waste package (data taken from Domski, 2004).

\begin{tabular}{|c|c|c|c|c|c|}
\hline Material & Formula & $\begin{array}{l}\text { Amount } \\
\text { (moles) }\end{array}$ & $\begin{array}{c}\text { Degradation } \\
\text { Rate } \\
(\mathrm{mol} / \mathrm{yr})\end{array}$ & Element & $\begin{array}{l}\text { Amount } \\
\text { (moles) }\end{array}$ \\
\hline A516 & $\begin{array}{l}\mathrm{Fe}_{1.76} \mathrm{Mn}_{0.019} \mathrm{C}_{0.0233} \mathrm{Si}_{0.0103} \mathrm{P}_{0.00} \\
{ }_{113} \mathrm{~S}_{0.00109}\end{array}$ & 59031 & 1348 & $\mathrm{Fe}$ & 227227 \\
\hline $316 \mathrm{SS}$ & $\mathrm{Fe}_{1.17} \mathrm{Cr}_{0.327} \mathrm{Ni}_{0.204} \mathrm{Mo}_{0.0261} \mathrm{Mn}_{0}$ & 105412 & 0.4 & 0 & 79924 \\
\hline CSNF & $\begin{array}{l}.0364 \\
\mathrm{U}_{0.3617} \dot{P}_{0.0027} \mathrm{O}_{0.7385}\end{array}$ & 108225 & 1.8 & $\mathrm{U}$ & 39145 \\
\hline & & & & $\begin{array}{l}\mathrm{Cr} \\
\mathrm{Ni}\end{array}$ & $\begin{array}{l}34470 \\
21504\end{array}$ \\
\hline
\end{tabular}

Notes: For simplicity the 316 SS formula lists 5 most abundant elements. CSNF lists the top 3. Borated stainless steel was originally part of the design but is being reconsidered and is therefore not shown here. Median molar degradation rates (mol/cm $\mathrm{cm}^{2} \mathrm{~s}$ ) and whole package surface areas $\left(\mathrm{cm}^{2}\right)$ are: A516-1.79 $\times 10^{-11} ; 2.39 \times 10^{6} ; 316 \mathrm{SS}-2.53 \times 10^{-14} ; 5.00 \times 10^{5}$. CSNF rates were calculated from the molar degradation rate $=1.12 \times 10^{-11}\left[\mathrm{pO}_{2}\right]^{-0.338}\left[\mathrm{pH}^{-0.34} \cdot \mathrm{pO}_{2}\right.$ is the negative base 10 logarithm of the oxygen partial pressure $(0.2$ atm here); saturation state effects were ignored, clad coverage was assumed to be $90 \% ; \mathrm{pH}=7$ (In-package pHs are expected to be from 4.5 to 8 (Domski, 2004 )). CSNF surface area $=2.28 \times 10^{7} \mathrm{~cm}^{2}$. CSNF rates will vary somewhat from the nominal value above depending on clad coverage and fluid chemistry. The density of A516 is $7.85 \mathrm{~g} / \mathrm{mL}$.

One hundred years after breach the waste package will consist of fuel assemblages buried in a thick inner zone of Fe(II)-containing minerals and possibly some un-corroded A516. An outer blanket will be made up of goethite, or hematite, and a great deal of un-corroded 316 stecl and CSNF. Note again that Fe will dwarf the $U$ in the package and that there should be a general shift from Fe(II)-containing minerals to Fe(III)-containing minerals with time (and distance from the center of the breached waste package). Radiolysis may result in local oxidation, but the presence of emplaced neutron poisons (e.g. gadolinium and/or boron) and oxidation of adjacent steels will tend to limit this (sce e.g. Smellie and Karlsson, 1999).

\section{Oxidation State near the Fuel}

Seepage will probably flow around the mass of the corrosion product assemblage because porosity will be occluded by the growth of ferric (hydr)oxides. Corrosion roughly doubles to triples the solid volume depending on the corrosion product(s) and the amount of occluded water. Moreover, because iron corrosion products form at sites where oxygen and water are present, the porosity reductions that ensue will primarily affect connected porosity and, therefore, limit the further access of water and oxygen. Hence, the reaction zone will tend to be self-sealing. It is reasonable to expect connected porosity and permeability to drop sharply in the first century when the A516 steel corrodes.

Spontaneous porosity and permeability reduction is routinely seen in corrosion of iron-based permeable reactive barriers used for groundwater treatment (e.g. Wilkin and McNeil, 2003). There are more analogous situations, most notably the 7 ton buried nail cache at the Roman fort of Inchtuthil (e.g. Miller et al., 2000). Located in present-day Perthshire, Scotland, Inchtuthil was the northernmost legionary fortress in the Roman Empire. It was abandoned in $87 \mathrm{AD}$ at which time a cache of roughly 1 million iron nails was buried $5 \mathrm{~m}$ deep in the unsaturated zone of a hill and covered with $3 \mathrm{~m}$ of compacted earth. When the hoard was excavated $\sim 2000$ years later in the 1950s, the interior nails were found to be largely un-corroded because oxidation of the exterior nails shielded them from oxygen and water (Miller et al., 2000).

Breached waste packages at Yucca Mountain are therefore predicted to spontaneously form selfsealed anoxic zones in otherwise oxidizing drifts: $\mathrm{Fe}(\mathrm{II})$-containing minerals near the fuel and $\mathrm{Fe}$ (III)-containing minerals on the outer edges. In the absence of oxygen fluxes through the outer fringe, equilibria between $\mathrm{Fe}(\mathrm{II})$ - and Fe(III)-containing minerals will likely control in situ 
oxygen levels in the anoxic zone. Magnetite-goethite and magnetite-hematite transformations suggest an anoxic zone ambient $\mathrm{P}_{\mathrm{O} 2}$ range between $10^{-72.38}$ and $10^{-77.64} \mathrm{~atm}$ (thermodynamic data are from Drever, 1982):

$$
\begin{array}{ll}
\mathrm{Fe}_{3} \mathrm{O}_{4}+3 / 4 \mathrm{O}_{2}+1 / 2 \mathrm{H}_{2} \mathrm{O} \leftrightarrow 3 \mathrm{FeOOH} & \mathrm{K}_{\text {mag-goeth }}=10^{58.23}: \mathrm{P}_{\mathrm{O} 2}=10^{-77.64} \mathrm{~atm} \\
2 \mathrm{Fe}_{3} \mathrm{O}_{4}+1 / 2 \mathrm{O}_{2} \leftrightarrow 3 \mathrm{Fe}_{2} \mathrm{O}_{3} & \mathrm{~K}_{\text {mag-hem }}=10^{36.19}: \mathrm{P}_{\mathrm{O} 2}=10^{-72.38} \mathrm{~atm}
\end{array}
$$

This corresponds to a $25^{\circ} \mathrm{C} \mathrm{pH} 7 \mathrm{E}_{\mathrm{H}}$ of roughly $-300 \mathrm{mV}$, conditions where CSNF does not dissolve and where $\mathrm{Tc}, \mathrm{Np}, \mathrm{Pu}$, and $\mathrm{U}$ solubilities are 5 to 10 orders of magnitude below their presently assumed $\mathrm{P}_{\mathrm{O} 2}=0.2 \mathrm{~atm}$ values. Access of oxygen and corrosion of CSNF would raise levels from this range. Corrosion of steel would send it lower still. If liquid water never appears inside breached waste packages, corrosion of steel would still cause corrosion products to accumulate around fuel elements, though their abundance and ability to limit oxygen movement might be less. 'Dry breaching' is less of a health threat because there would be no transport pathways from the waste package for radionuclides.

The potential reduction in radionuclide fluxes that comes from anoxia dwarfs most, if not all, other radionuclide retardation processes, natural or engineered. The critical question for fuel degradation and radionuclide transport at Yucca Mountain is how tightly coupled will be the $\mathrm{Fe}(\mathrm{III}) / \mathrm{Fe}$ (II) mineral redox buffer. The buffer's effectiveness will depend on the operation of two processes: one physical, the self-sealing of corrosion products, and one chemical, the rapid dissolution of $\mathrm{Fe}$ (II) or $\mathrm{Fe}(0)$ solids in response to the presence of oxygen. The $\mathrm{Fe}(\mathrm{III}) / \mathrm{Fe}$ (II)mineral redox buffer that formed at Inchtuthil was so tightly coupled as to maintain oxygen-free conditions for roughly 2000 years, indeed until the site was excavated.

Much of the technical debate about Yucca Mountain focuses on the effectiveness of the Alloy 22 barrier and the presumed hydrologic linkage between the waste package and the biosphere. The results above suggest that degradation inside the waste package carries with it its own peculiar geochemical barrier and hydrogeology which together may be the far more critical control over radionuclide release.

\section{References Cited}

Domski P. S. (2004) In-package chemistry abstraction for wasteforms at Yucca Mountain; Rev 03B. BSC-DOE. Yucca Mtn. Project Office.

Drever J. I. (1982) The Geochemistry of Natural Waters. Prentice-Hall.

Forsberg C. W. and Dole C. W. (2003) Maintaining chemically reducing waste-package conditions. Mat. Rs. Soc. Symp. Proc. 757, 677-683.

Lerman A. (1985) Geochemical Processes: Water and Sediment Environments. John Wiley \& Sons.

Miller W., Alexander R., Chapman N., McKinley I., and Smellie J. (2000) Geological disposal of radioactive wastes and natural analogues; Lessons from nature and anthropology. Pergamon.

Smellie J. and Karlsson F. (1999) The use of natural analogues to assess radionuclide transport. 
Engineering Geology 52, 193-220.

Stockman H. W. and LeStrange S. (2000) In-drift accumulation of fissile material from waste packages containing plutonium disposition waste forms, pp. 53. Office of Civilian Radioactive Waste Management.

Wilkin R. T. and McNeil M. S. (2003) Laboratory evaluation of zero-valent iron to treat water impacted by acid mine drainage. Chemosphere 53, 715-725.

Winograd I. J., Coplen T. B., Landwehr J. M., Riggs A. C., Ludwig K. R., Szabo B. J., Kolesar P. T., and Revesz K. M. (1992) Continuous 500,000 year climate record from vein calcite in Devils Hall, Nevada. Science 258, 255-260. 


\section{In Drift Flow}

Eric Sonnenthal

Earth Sciences Division

Lawrence Berkeley National Laboratory

1 Cyclotron Road Mail Stop 90R1116

Berkeley, CA 94720

\section{Email: ELSonnenthal@lbl.gov}

The effectiveness of the potential repository at Yucca Mountain in preventing radioactive waste from entering the accessible environment is related to the quantity and chemistry of water that may seep into the emplacement drifts and which may percolate into the rock beneath the drifts and migrate to the water table (saturated zone). In-drift flow processes are therefore dependent on the fluxes of water into drifts. There are three potential sources of water within drifts: (1) seepage water that results from either dripping from the drift crown, film flow along the walls, or by capillary "wicking" into the invert, (2) condensation of water vapor, and (3) deliquescence of salts. The flux of water into the drift via seepage (BSC 2004 b,c) is dependent on the surface infiltration rate (net water flux passing through the soil zone after undergoing evapotranspiration).

Heat generated by the decay of radioactive waste at Yucca Mountain will result in coupled thermal-hydrological-chemical (THC) processes in the host-rock around waste-emplacement tunnels (drifts) and within the in-drift environment. Temperatures in near-field (the region extending several meters into the host rock) are expected to remain above ambient background temperatures for thousands of years after waste emplacement. The thermal load resulting from the current repository design has been predicted to yield boiling conditions in the near-field for a few hundred to a few thousand years after site closure, depending on the location (Buscheck et al., 2003; Haukwa et al., 2003). Resulting near-field THC processes have been extensively studied (Sonnenthal et al., 2003, in press; Spycher et al., 2003ab, BSC 2004a). Boiling of water in the unsaturated rock matrix generates vapor that migrates away from the drift through permeable fractures and then condenses in cooler regions and drains back toward the drift through the fracture network. This boiling and refluxing of water is accompanied by changes in pore-water and gas compositions as well as mineral dissolution and precipitation. Mineral alteration, dissolution, and precipitation, particularly in the boiling zones, result in porosity and permeability changes in the rock. These changes, in turn, can result in water redistribution and altered flow paths in the rock, often resulting in flow focussing (Sonnenthal et al., 2003; Haukwa et al., 2003).

The development of a dry zone around drifts, resulting from evaporation and boiling (the "vaporization barrier"), will reduce significantly the possibility of in-drift seepage during the boiling period (Birkholzer et al., 2004). Simulations have shown that after the boiling period, seepage into the emplacement drift is largely impeded by the capillary barrier effect of the drift openings (i.e., the effect of capillary forces acting at the rock-air interface of the drift wall). The capillary barrier can be broken by flow focussing resulting from fracture permeability 
heterogeneity and from mineral precipitation/dissolution effects, most particularly under elevated percolation fluxes (Haukwa et al., 2003, Sonnenthal et al., 2003). Condensation of vapor inside the drift can provide another significant source of in-drift water. Once inside the drift (either through seepage or condensation), water is expected to drip onto the drip shield or on the waste package once the drip shield has been compromised. At this point the water may evaporate, leaving behind salts, flow into a breached waste package, or continue flowing into the crushed tuff invert below the waste packages. If flow into the waste package takes place, then dissolution of the waste form can lead to radionuclide-bearing water that flows into the invert and eventually into the rock at the base of the drift. Owing to the small fluxes of water expected in the drifts, the invert and the environment around the waste package will remain unsaturated and, therefore, in communication with a gas phase. Water that flows along the drift wall will mostly flow into the invert at the bottom of the drift.

\section{Acknowledgments}

Sumit Mukhopadhyay and Nicolas Spycher contributed to the work presented in this summary. This work was supported by the Director, Office of Civilian Radioactive Waste Management, U.S. Department of Energy, through Memorandum Purchase Order QA-B004220RB3X between Bechtel SAIC Company, LLC and the Ernest Orlando Lawrence Berkeley National Laboratory (Berkeley Lab).

\section{References}

(1) Birkholzer, J.T., Mukhopadhyay, Tsang, Y.W. Vadose Zone Journal. 2004, 3, 819-836.

(2) Haukwa C.B., Y.W. Tsang, Y.-S. Wu, and G.S. Bodvarsson. J. Contaminant Hydrology, 2003, 62-63, 509-527.

(3) BSC 2004a. Drift-Scale THC Seepage Model. MDL-NBS-HS-000001 REV 03. Las Vegas, Nevada: Bechtel SAIC Company. DOC.20041201.0008.

(4) BSC 2004b. Seepage Model for PA Including Drift Collapse. MDL-NBS-HS-000002 REV 03. Las Vegas, Nevada: Bechtel SAIC Company. DOC.20040922.0008.

(5) BSC 2004c. Seepage Calibration Model and Seepage Testing Data. MDL-NBS-HS000004 REV 03. Las Vegas, Nevada: Bechtel SAIC Company. DOC.20040922.0003.

(6) Buscheck T.A., N.D. Rosenberg, J.A. Blink, Y. Sun, J. Gansemer. J. Contaminant Hydrology, 2003, 62-63: 441-457.

(7) Sonnenthal E., A. Ito, N Spycher, M. Yui, J. Apps, Y. Sugita, M. Conrad, and S. Kawakami. Int. J. Rock Mech. Min. Sci., in press.

(8) Sonnenthal, E., N. Spycher, and T. Xu. Proceedings of the TOUGH Symposium 2003. Lawrence Berkeley National Laboratory, 2003.

(9) Spycher, N, E. Sonnenthal, and J. Apps,. J. Cont. Hydrol., 2003a, 62-63: 653-673.

(10) Spycher N, E. Sonnenthal, P. Dobson, J. Apps, S. Salah, T. Kneafsey, and C. Haukwa,. Drift-scale coupled processes (DST and THC seepage) models, REV02. Report LBID2478 Lawrence Berkeley National Laboratory, Berkeley, CA, $2003 \mathrm{~b}$. 


\section{SECTION 2:}

Traditional GetTer Materials

Page 20 of 55 


\section{Getter Materials for Neptunium: Thermodynamic Features of $\mathrm{Np}$ in the Environment and} What Has Been Done

Ken Nash

Chemistry Department

Washington State University

PO Box 644630

Pullman, WA 99164-4630

Email: knash@wsu.edu

Spent fuel from the operation of light water reactors fueled with 3-4\% enriched uranium produces about $500 \mathrm{~g} /$ ton of ${ }^{237} \mathrm{~Np}$ as a byproduct. This isotope has a half-life of $2.1 \times 10^{6}$ years, and thus is one of the longest-lived radioactive components of spent nuclear fuel. The nature of its chemistry is such that upon release from the repository environment, it can be expected to exhibit moderate mobility in the environment, under-oxidizing condition in particular. Developing the means for its retardation in the immediate repository environment is therefore a priority in overall repository performance assessment. Though $\mathrm{Np}$ environmental chemistry has been the subject of a number of investigations during the past three decades, the development of getter materials has not received much attention. The following is a synopsis of the current state understanding of neptunium chemistry as it is relevant to the question of developing getter materials.

The redox potentials of the actinides in acidic solutions are well known. Limiting potentials in basic media are less firmly established but, in general, can be considered known with adequate precision. At environmental pH's, potentials reside between these limits and respond to the degree of complexation of the metal ions. It is generally accepted that to a first approximation actinide ions in a given oxidation state behave similarly; thus, the chemistries of Am(III), Th(IV), $N p(V)$ and U(VI), the most stable oxidation states of these metal ions, are generally representative of all actinides in these oxidation states. This concept has proven in environmental chemistry to be most useful in the realization that $\mathrm{Np}(\mathrm{V})$ serves as a good substitute for $\mathrm{Pu}(\mathrm{V})$, which for a variety of reasons is difficult to study directly. As a rule, the relative order of complex stability of the actinide oxidation states are An(IV) $>A n(V I)>A n(I I I)>A n(V)$. Their susceptibility to hydrolysis follows the same order with the onset of hydrolysis for the respective oxidation states occurring at $\mathrm{pH} 0.5$ (An(IV)), $\mathrm{pH} 3-4$ (An(VI)), $\mathrm{pH}$ 5-7 (An(III)), and pH 8-9 for $\mathrm{An}(\mathrm{V})$. At high concentrations, tetravalent actinides form soluble hydrolytic polymers that are comparatively kinetically inert and, therefore, resistant to decomposition. At low concentrations, actinide ions tend to form "radiocolloids," adsorbing to mobile colloidal material. These radiocolloids significantly alter the behavior of trivalent and tetravalent actinide ions (in particular) in solutions under these conditions. The presence of radiocolloids causes unpredictable behavior, in particular, either enhancing apparent solubility/mobility or increasing adsorption on surfaces, depending on conditions. The pentavalent and hexavalent cations exist under environmentally relevant conditions as linear dioxocations, exhibiting effective cationic charges in their coordination compounds of +2.2 and +3.3 , respectively. The most important 
soluble environmental complexes of these ions are the carbonates. The triscarbonato complex of $\mathrm{U}(\mathrm{VI})\left(\mathrm{UO}_{2}\left(\mathrm{CO}_{3}\right)_{3}{ }^{4-}\right)$ is particularly significant.

Neptunium species have been prepared in five oxidation states (III, IV, V, VI, and VII). Under all conditions, $\mathrm{Np}$ (III) is readily oxidized, while $\mathrm{Np}(\mathrm{VII})$ and $\mathrm{Np}(\mathrm{VI})$ are either strongly or moderately oxidizing (i.e., easily reduced) under most conditions. $\mathrm{Np}$ (VII) can only be prepared in strongly basic solutions. $\mathrm{Np}(\mathrm{VI})$ is found in spent nuclear fuel dissolver solutions (3-4 M $\mathrm{HNO}_{3}$ ), which leads to interesting complications in the operation of the PUREX process for $U$ and $\mathrm{Pu}$ recycle. Under environmental conditions of $\mathrm{pH}, \mathrm{Np}(\mathrm{V})$ and $\mathrm{Np}(\mathrm{IV})$ are the only important species. $\mathrm{Np}(\mathrm{IV})$ is strongly complexed by a wide variety of complexants, but $\mathrm{Np}$ (IV) is also readily hydrolyzed and precipitated as $\mathrm{NpO}_{2} / \mathrm{Np}(\mathrm{OH})_{4}$. In the reduced form, $\mathrm{Np}$ behaves similarly to $\mathrm{Pu}(\mathrm{IV})$, though the oxide is far easier to dissolve with oxidation than $\mathrm{PuO}_{2}$. In contrast, $\mathrm{NpO}_{2}{ }^{+}$is weakly complexed by most ligands and in general does not form insoluble compounds under most environmentally relevant conditions.

The important role of $\mathrm{Np}$ chemistry in the characterization of repository performance has been recognized for some time. There have been investigations of the chemistry of neptunium under repository-relevant conditions conducted around the world during the past 25-30 years. A computer-based survey of the literature examining specifically "neptunium sorption" produced approximately 180 citations relevant to the topic. Those reports can be readily summarized under the following topical areas.

\section{Neptunium interactions with various mineral surfaces}

Neptunium association with a variety of different mineral surfaces has been investigated in association with various international efforts at devising repository disposition strategies. Among the most important rock types studied are volcanic tuffs, granites, basalt, and salt deposits. Minerals containing elements in reduced valence states more successfully retain $\mathrm{Np}$ than oxidized mineral surfaces.

\section{Neptunium sorption to iron oxide phases}

Biotite and magnetite exhibit some ability to retain $\mathrm{Np}$. Hematite and goethite generally do not retain $\mathrm{Np}(\mathrm{V})$ strongly. There is some evidence for increased retention of $\mathrm{Np}$ when sorbed onto freshly precipitated iron oxides/hydroxides as they mineralize into more durable species.

\section{The effect of redox conditions}

One common feature of neptunium sorption is that conditions reducing enough to transform $\mathrm{Np}(\mathrm{V})$ into $\mathrm{Np}(\mathrm{IV})$ result in greater association of $\mathrm{Np}$ with surfaces. Oxidizing conditions favor the presence of $\mathrm{NpO}_{2}{ }^{+}$, which interacts weakly with most species and forms few insoluble compounds under environmental conditions. Its unique coordination geometry and low charge are most responsible for these features.

\section{The effect of organic compounds, humic materials, biological systems}

Organic compounds, particularly man-made reagents like EDTA, in general tend to promote solubility and mobility of $\mathrm{Np}$. Humic matter does not generally reduce $\mathrm{Np}$ below the pentavalent oxidation state and can either promote or retard environmental mobility depending on the size of the humic matter. The few studies that have been done of the interactions of $\mathrm{Np}$ with biological 
materials indicate moderate association of $\mathrm{Np}$ with cellular materials, which contain abundant phosphate and carboxylate groups.

\section{Clays and colloids, soils and sediments}

Alumina and silica each have different effects on $\mathrm{Np}$ solubility dependent on conditions and the morphology of the solids. Aluminosilicates in the form of clays and colloids can have a profound effect on the potential for $\mathrm{Np}$ mobility, though they lack any specificity in their interactions with Np. Sorption onto bulk clay minerals can be moderate. Precipitation of large colloidal particles (or aggregates) in mineral fissures has been shown to decrease fluid mobility through fissures, retarding $\mathrm{Np}$ along with any other potentially mobile cations. Soils and sediments exhibit similarly a range of behaviors. Reducing clays sorb Np more efficiently than oxidizing clays, presumably due to reduction and irreversible sorption of $\mathrm{Np}$ (IV).

\section{Cement and concrete}

Alkaline materials of this variety have been shown in general to exhibit high affinity for neptunium under a wide variety of conditions. It has been noted that waters flowing past concrete surfaces underground tend to create an alkaline plume. This feature may be desirable for actinide retention in the repository environment but may have other deleterious effects, including impacting ground water composition.

In summary, it has been observed that oxidized neptunium $(\mathrm{Np}(\mathrm{V}))$ is weakly sorbed to most surfaces, is not strongly. complexed by any environmentally important organic or inorganic complexing agent (though soluble carbonates and hydroxides are known), and is not generally solubility-limited under neutral $\mathrm{pH}$, low ionic-strength conditions. There are some indications of reduced $\mathrm{Np}$ solubility in the presence of both calcium and phosphate and at least one report of $\mathrm{Np}(\mathrm{V})$ having been incorporated into the molecular structure of some uranyl solids of environmental relevance. $\mathrm{Np}(\mathrm{V})$ exhibits minimal tendency to associate with oxidized iron mineral species, but magnetite $\left(\mathrm{Fe}_{3} \mathrm{O}_{4}\right)$ generally exhibits high $\mathrm{Np}$ partitioning coefficients resulting from the reduction of $\mathrm{Np}(\mathrm{V})$ to the markedly less soluble $\mathrm{Np}(\mathrm{IV})$. Unlike plutonium, $\mathrm{Np}$ (IV) tends not to remain insoluble unless reducing conditions are maintained-it is more readily oxidized to $\mathrm{Np}(\mathrm{V})$ (for example on contact with dissolved oxygen) and resolubilized than is $\mathrm{Pu}(\mathrm{IV})$. The ideal conditions for $\mathrm{Np}$ retention would appear to be to maintain a moderately alkaline-reducing environment in which $\mathrm{NpO}_{2}$ would be the dominant species. Designing robust getters for $\mathrm{Np}(\mathrm{V})$ faces the challenge of the inherently weak interaction of a low-charged cation with most materials. Under oxidizing conditions an ion recognition material that can somehow accommodate the reduced charge of $\mathrm{NpO}_{2}{ }^{+}$without its displacement by $\mathrm{UO}_{2}{ }^{2+}$ (which will under any rational conditions be present in significant excess over $\mathrm{Np}$ ) will be required. Uranyl mineral phases and alkaline earth phosphates (or possibly other phosphate phases) would appear to be viable candidates. Engineered materials could have a positive impact, but maintaining an acceptably low cost of the material and assuring stability over geologic timescales will be a challenge. 


\section{Iodine Chemistry and Potential Iodine Getters}

\section{J. Clara Wren}

Department of Chemistry

University of Western Ontario

London, Ontario, Canada N6A 5B7

\section{Email: jcwren@uwo.ca}

The primary factors in choosing a getter for iodine under waste disposal conditions are perhaps (1) iodine speciation (an issue due to the wide range of chemical reactivity and different mobilities of iodine species), (2) the iodine adsorption (or absorption) capacity of the getter, (3) iodine sorption kinetics on the getter, and (4) the stability of the adsorbed iodine on the getter.

The chemistry of iodine speciation under the waste disposal conditions could be complex since iodine can exist in a wide range of oxidation states $(-1$ to +7$)$ in the aqueous phase (e.g., $\mathrm{I}^{-}, \mathrm{I}_{2}$, $\left.\mathrm{I}_{3}^{-}, \mathrm{HOI}, \mathrm{IO}_{2}^{-}, \mathrm{IO}_{3}^{-}, \mathrm{IO}_{4}^{-}\right)$. Over the temperature range expected for the disposal conditions, only a small subset of these species would be in fast equilibrium. These species also exhibit wide ranges of chemical reactivity, volatility, and transport properties. To find optimum iodine getters, it is important to understand time-dependent iodine speciation under the waste disposal conditions. Because of widely different chemical reactivity and mobility, thermodynamic considerations alone will not suffice to determine time-dependent iodine speciation. The chemical reaction kinetics and transport of the iodine species must be considered. This is particularly important in the presence of radiation.

The reaction kinetics and transport of iodine species in the presence of radiation has been extensively studied under nuclear reactor post-accident containment conditions [1,2]. Although different to the waste disposal conditions, the reaction kinetics and transport behavior observed under accident conditions could be relevant and applicable, especially those studies of iodine interactions with, and transport on, various surfaces and solid adsorbents. Such studies have included iodine interaction with silver [3], zinc, steel, and painted surfaces in the aqueous phase, and with steel [4], aluminum, painted surfaces, and highly activated charcoal $[5,6]$ in the vapor phase. Based on these studies, silver (aqueous iodine species) and activated charcoal (gaseous iodine species) are potentially good iodine getters. These studies will be summarized in this presentation.

In the presence of radiation, the aqueous chemistry of iodine and the inter-conversion between iodine species would be driven mainly by reactions with water radiolysis products:

$$
\mathrm{H}_{2} \mathrm{O} \stackrel{\alpha, \beta, \gamma}{\longrightarrow} \mathrm{e}_{\mathrm{aq}}^{-}, \cdot \mathrm{H}, \cdot \mathrm{OH}, \mathrm{H}_{2} \mathrm{O}_{2}, \mathrm{HO}_{2}, \mathrm{H}^{+}, \mathrm{H}_{2}
$$

with the key iodine-oxidation reactions being

$$
\begin{array}{lll}
\mathrm{I}^{-}+\bullet \mathrm{OH} & \rightarrow \mathrm{I} \cdot+\mathrm{OH}^{-} \\
\mathrm{I} \bullet+\mathrm{I}^{-} & \rightarrow \rightarrow \mathrm{I}_{2}\left(\mathrm{via} \mathrm{I}_{2}^{-}\right)
\end{array}
$$


and the reduction of $\mathrm{I}_{2}$ back to $\mathrm{I}^{-}$being

$$
\begin{aligned}
& \mathrm{I}_{2}+\mathrm{H}_{2} \mathrm{O}=\mathrm{HOI}+\mathrm{I}^{-}+\mathrm{H}^{+} \\
& \mathrm{I}_{2}+\cdot \mathrm{O}_{2}^{-} \rightarrow \mathrm{I}^{-}+\mathrm{I}^{-}+\mathrm{O}_{2} \\
& \mathrm{I}_{2}+\mathrm{H}_{2} \mathrm{O}_{2} \rightarrow 2 \mathrm{I}^{-}+2 \mathrm{H}^{+}+\mathrm{O}_{2}
\end{aligned}
$$

Independent of the nature of the iodine species in the waste form, once the iodine escapes the waste form into any water present, the iodine chemistry would be dominated by its radiolysisdriven reactions. Because the reactive water-radiolysis products are continuously produced in a radiation field, the iodine system would not be chemically conserved and, hence, would not be in thermodynamic equilibrium. However, due to the highly reactive nature of water radiolysis products, the system may reach steady state. The oxidation and reduction rates of iodine would strongly depend on the water-radiolysis product concentrations. The overall dependence of iodine speciation on $\mathrm{pH}$, temperature and radiation dose rate can then be rationalized. However, reactions catalyzed by other species present (e.g., transition metal ions such as $\mathrm{Fe}^{2+} / \mathrm{Fe}^{3+}$ and nitrate/nitrite ions) and surfaces must be taken into consideration as they could have a significant impact on the water radiolysis product concentrations. The chemistry of iodine in the presence of radiation and the various parameters that could have significant impact on iodine speciation will be reviewed. The important factor, however, is that the radiolysis reactions would ensure that the iodine is continuously transformed into a species that can react with the chosen getter material.

Silver iodide has a low vapor pressure and low solubility in water, which makes silver an attractive getter for iodine. A substantial amount of information is available on the ability of silver to react with iodine. The adsorption kinetics of aqueous iodine species on silver in the presence of radiation have been studied as a function of $\mathrm{pH}$, silver surface area, and initial $\left[\mathrm{I}^{-}\right]$at $90^{\circ} \mathrm{C}$ in the Radioiodine Test Facility (RTF) [3]. The adsorption kinetics followed a first-order dependence on the total aqueous iodine concentration and were successfully modeled assuming that $I_{2}$, formed by radiolytic processes, is the reacting species. Iodine adsorption on silver was extensive, 100 - 1000 monolayers, and appears only to be limited by the amount of available dissolved iodine. The adsorption rate constant extracted from model simulations was $0.01 \mathrm{dm} \cdot \mathrm{s}^{-1}$, indicating that the adsorption might be mass transport limited. Although these simulations have reproduced the data reasonably well, it has been suggested that iodine could be adsorbed on silver via the reaction of $\mathrm{I}^{-}$with silver oxides. Therefore, current electrochemical and surface analytical studies focus on establishing the reaction kinetics of $\mathrm{I}_{2}$ and $\mathrm{I}^{-}$with $\mathrm{Ag}$ either in the reduced metallic form $\left(\mathrm{Ag}^{\circ}\right)$ or in an oxidized state ( $\mathrm{Ag}^{\mathrm{l}} / \mathrm{Ag}^{\mathrm{II}}$ oxide/hydroxide). The results from the RTF and modeling studies will be presented and the various proposed mechanisms reviewed.

Nuclear-grade activated charcoal has a very large surface area, of the order of $1000 \mathrm{~m}^{2} / \mathrm{g}$ charcoal, and hence is potentially a good getter for gaseous iodine species, including organic iodides that are normally difficult to capture. Factors to consider for a getter would be the potential degradation of charcoal due to aging, the adsorption of water vapour and other air contaminants, and the desorption of iodine over long-term airflow conditions. Iodine adsorption and transport through activated charcoal beds under simulated accident conditions has been studied extensively [5,6], including the effects of aging and pre-adsorbed air contaminants $\left(\mathrm{SO}_{2}\right.$, $\mathrm{NO}_{\mathrm{x}}$, etc) and the transient temperature and water adsorption behavior. The charcoal used in 
these studies is highly activated granular charcoal impregnated with triethylenediamine (TEDA) to increase the trapping efficiency for organic iodides. These studies have shown an extremely large adsorption capacity for iodine species, making them very effective in removing and retaining $\mathrm{CH}_{3} \mathrm{I}$ from airstreams under postulated accident conditions. The adsorption on and transport of iodine through a charcoal bed was also modeled successfully using a onedimensional model, consisting of the transport terms due to convection and diffusion and a term for adsorption kinetics. The kinetic term is complicated, however, due to the presence of two different adsorption sites, bare charcoal surface and TEDA impregnants. Iodine adsorption and desorption rates from these distinctive sites have been determined independently as a function of temperature, relative humidity, and flow rate. The adsorption and transport behavior of iodine through a charcoal bed under flowing conditions will be reviewed, and the impacts of air contaminants and water vapor adsorption on the charcoal adsorption efficiency will be summarized. From the perspective of a getter for airborne iodine, the use of a charcoal filter, the aging of the charcoal (degradation of its capacity), and long-term release of material are issues. The use of an Ag-impregnated charcoal (or silver zeolite) could replace the problem of long-term release, but the behavior of this material is not as well known as the TEDA-impregnated, nuclear-grade charcoal.

\section{Acknowledgements}

The work discussed here was performed under a CANDU Owners Group Research and Development Program, jointly supported by Ontario Power Generation, Bruce Power, Hydro Quebec, New Brunswick Power, and AECL.

\section{References}

1. J.C. Wren and, J.M Ball, "LIRIC 3.2 An Updated Model for Iodine Behaviour in the Presence of Organic Impurities," Rad. Phys. Chem., 60, 577 (2001).

2. J.C. Wren, J.M. Ball and G.A. Glowa, "The Chemistry of Iodine in Containment", Nucl. Tech., 129, 297 (2000).

3. (a) J.C. Wren, G.A. Glowa and J. Merritt, "Corrosion of Stainless Steel by Gaseous Iodine", J. Nucl. Material, 265, 161 (1999); (b) J.C. Wren and G.A. Glowa, "Kinetic of Gaseous Iodine Uptake Onto Stainless Steel During Iodine-Assisted Corrosion," Nucl. Tech, 133, 33 (2001).

4. J.C. Wren, G.A. Glowa and J.M. Ball, "Summary of PHEBUS RTF Programme", in Proceedings of the $4^{\text {th }}$ PHEBUS Seminar, Marseille, France, March 22, (2000).

5. J.C. Wren, W. Long, C.J. Moore and K.R. Weaver, "Modelling the removal and Retention of Radioiodine by TEDA-Impregnated Charcoal under Reactor Accident Conditions", Nucl. Tech. 125, 13 (1999).

6. (a) J.C. Wren and C.J. Moore, "The Effect of Weathering on Charcoal Filter Performance. I: The Adsorption and Desorption Behaviour of Contaminants", Nucl. Tech. 94, 242 (1991); (b) J.C. Wren and C.J. Moore, "The Effect of Weathering on Charcoal Filter Performance. II: The Effect of Contaminants on the $\mathrm{CH}_{3} \mathrm{I}$ Removal Efficiency of TEDA Charcoal", Nucl. Tech. 94, 252 (1991). 


\section{Traditional Getters for Tc}

Brian Viani

Lawrence Livermore National Laboratory

7000 East Avenue

Livermore, CA 94550

Email: viani1@llnl.gov

No synopsis submitted. 


\section{Development of Selective Ion Exchange and Carbon-Based Getters for Pertechnetate Sorption}

Baohua Gu

Environmental Sciences Division

Oak Ridge National Laboratory

PO BOX 2008, MS6036

Oak Ridge, TN 37831-6036

Email: b26@ornl.gov

Oak Ridge National Laboratory has been actively involved in the development of selective ion exchange and activated-carbon-based getter materials for pertechnetate $\left(\mathrm{TcO}_{4}{ }^{-}\right)$sorption. These getter materials could potentially be used to retain $\mathrm{TcO}_{4}{ }^{-}$in the event of accidental leakages from the Yucca Mountain High-Level Waste Repository. A new class of bifunctional anion-exchange resins was designed to selectively and effectively remove $\mathrm{TcO}_{4}^{-}$from contaminated water containing orders of magnitude higher concentrations of competing anions such as nitrate, sulfate, carbonates, and chloride. These resins have two quaternary ammonium functional groups, one having long chains for higher selectivity and one having shorter chains for improved reaction kinetics. The measured distribution coefficient $\left(K_{d}\right)$ for $\mathrm{TcO}_{4}^{-}$sorption exceeded $\sim 40,000 \mathrm{~mL} / \mathrm{g}$ on bifunctional anion-exchange resins. Additionally, sorption of $\mathrm{TcO}_{4}{ }^{-}$on activated carbon was studied in both batch and column leaching studies. Activated carbon also was found to selectively and effectively sorb $\mathrm{TcO}_{4}{ }^{-}$over a wide range of $\mathrm{pH}$ values and from various background solutions (with competing anions). The $K_{d}$ values exceeded $27,000 \mathrm{~mL} / \mathrm{g}$ when the reaction was tested in a groundwater and exceeded $12,000 \mathrm{~mL} / \mathrm{g}$ when background solutions of $0.01 \mathrm{M} \mathrm{CaCl}_{2}$ and $\mathrm{Na}_{2} \mathrm{SO}_{4}$ were used. Technetium removal efficiency was $>99 \%$ under these conditions, except in a $0.01 \mathrm{M} \mathrm{NaNO}_{3}$ background solution. Column studies confirmed a high-sorption capacity and selectivity of activated carbon for $\mathrm{TcO}_{4}{ }^{-}$. Because of its low cost and availability, activated carbon perhaps could be used as one of the most robust sorbent materials for sorbing $\mathrm{TcO}_{4}{ }^{-}$in the waste repository. Future studies may further modify the surfaces of these sorbent materials with improved exchange sites and heat resistance, thereby increasing the sorption capacity and long-term stabilization of sorbed $\mathrm{TcO}_{4}{ }^{-}$. 


\section{SECTION III:}

NANOPOROUS MATERIALS

Page 29 of 55 


\title{
Strategic Design of Sorbents for Cesium, Strontium, and Actinide Removal from Nuclear Waste Systems
}

\author{
Abraham Clearfield \\ Department of Chemistry \\ Texas A\&M University \\ College Station, TX 77842

\section{Email: clearfield@mail.chem.tamu.edu}

Our immediate objective is to design ion exchangers and sorbents for the removal of high-level radioactive species from the fluid portion of tank waste. These species include $\mathrm{Cs}^{+}, \mathrm{Sr}^{2+}$, and actinides. The long range objective is to determine the origin of selectivity in the sorbents under consideration.

Two types of sorbents are being studied: a series of crystalline ion exchangers that have framework structures enclosing tunnels or cavities, and amorphous exchangers, such as monosodium titanate (MST). This study is a collaborative one that includes a group at the Westinghouse Savannah River National Laboratory headed by Dr. David Hobbs, Dr. May Nyman at Sandia National Laboratory, and theoretical studies by Dr. Edward J. Maginn at Notre Dame University.

The most highly selective ion exchanger for $\mathrm{Cs}^{+}$is a sodium titanium silicate of composition $\mathrm{Na}_{2} \mathrm{Ti}_{2} \mathrm{O}_{3} \mathrm{SiO}_{4} \cdot 2 \mathrm{H}_{2} \mathrm{O}$ erroneously named crystalline silica titanate (CST). It is actually a sodium titanium silicate. $^{1,2}$ The crystals are tetragonal $\mathrm{a}=7.808, \mathrm{c}=11.973 \AA$. The $\mathrm{Ti}$ atoms occur in clusters of four octahedra with the inner core a distorted $\mathrm{Ti}_{4} \mathrm{O}_{4}$ cubane type structure. These clusters are bridged together in the a- and b-axis directions by silicate groups, as shown in Figure 1. This arrangement results in tunnels running parallel to the c-axis direction. Half the $\mathrm{Na}^{+}$and the water reside within the tunnels. The remaining $\mathrm{Na}^{+}$resides in smaller cavities within the framework walls. $\mathrm{Cs}^{+}$displaces the $\mathrm{Na}^{+}$within the tunnels, forming an 8-coordinate complex with the silicate oxygens. The $\mathrm{Cs}-\mathrm{O}$ bond distances are roughly equal to the sum of the ionic radii of these two ions.

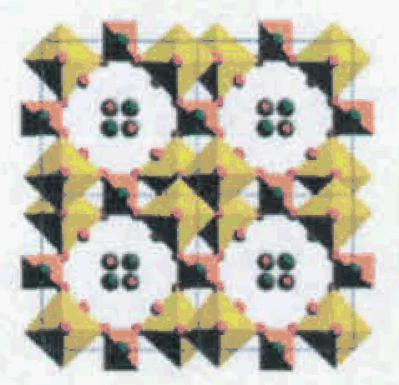

Figure 1. Polyhedral representation of the silicotitanate structure, top view, illustrating the formation of tunnels parallel to the $\mathrm{c}$-axis direction. $\mathrm{Na}^{+}$and $\mathrm{H}_{2} \mathrm{O}$ reside in the tunnel.

While $\mathrm{Cs}^{+}$selectivity is very high in CST, it rapidly diminishes in the presence of higher concentrations of $\mathrm{Na}^{+}$. However, by substituting $25 \% \mathrm{Nb}^{5+}$ for $\mathrm{Ti}^{4+}$, the selectivity is improved to the extent that it does pick up sufficient $\mathrm{Cs}^{+}$in $6 \mathrm{M} \mathrm{NaNO}_{3}$ and $1 \mathrm{M} \mathrm{NaOH}$ to meet DOE 
requirements for $\mathrm{Cs}^{+}$removal from Tank Waste. ${ }^{3,4}$ The reason for the enhanced $\mathrm{Cs}^{+}$selectivity was shown to result from the fact that in the $\mathrm{Nb}$ phase the cesium is 12-coordinate being bonded to four water molecules in addition to the 8-framework oxygens.

Strontium exchange by CST is also being pursued. ${ }^{3,4}$ Being small and more highly charged, $\mathrm{Sr}^{2+}$ finds different sites than $\mathrm{Cs}^{+}$. In the Nb-CST it is 7-coordinate, but in the pure CST it is 10coordinate, a reversal from the behavior of $\mathrm{Cs}^{+}$. This reversal may in part be due to the higher repulsion of $\mathrm{Sr}^{2+}$ by the more highly charged $\mathrm{Nb}^{5+}$ versus $\mathrm{Ti}^{4+}$.

One of the problems in utilizing CST for cesium ion removal is the effect of potassium ion. We have synthesized a member of the pharmacosiderite family that prefers $\mathrm{K}^{+}$over all other alkali metal ions. ${ }^{4}$ Pharmacosiderites of the type referred to have tetrameric $\mathrm{Ti}_{4} \mathrm{O}_{4}$ clusters of the same type as CST. However, they are cubic with cavities in the framework rather than as tunnels. Potassium ion forms a 12-coordinate complex in the face centers of the cube with bond distances equal to the sum of the $\mathrm{K}^{+}, \mathrm{O}^{2-}$ radii. By addition of this solid to the tank solution in the $\mathrm{H}^{+}$form, $\mathrm{K}^{+}$may effectively be removed so as not to interfere with the uptake of $\mathrm{Cs}^{+}$by CST.

Sodium nonatitanate (SNT) is a poorly crystalline layered compound of composition $\mathrm{Na}_{4} \mathrm{Ti}_{9} \mathrm{O}_{4} \cdot \mathrm{H}_{2} \mathrm{O}{ }^{5}$ It has a high affinity for $\mathrm{Sr}^{2+}$ and has been tested successfully to remove $\mathrm{Sr}^{2+}$ at the Savannah River site. ${ }^{6}$ In a surprising discovery it was shown that SNT is a precursor to the formation of CST the silicotitanate. ${ }^{7}$ By carrying out in situ experiments at the Brookhaven synchrotron, the hydrothermal synthesis of CST was observed by obtaining X-ray powder patterns every 2.5 minutes in situ. The SNT forms first and depending upon conditions transforms to CST in a period of 1-3 hours. Our idea is to provide a mixture of SNT and CST for in-tank sequestration of $\mathrm{Cs}, \mathrm{Sr}$, and actinides in a single step. Preliminary tests indicate high removal of targeted species.

At present, MST is the baseline sorbent for removal of the targeted species except $\mathrm{Cs}^{+}$from Savannah River Tank Waste. ${ }^{6}$ It is amorphous with composition approximately $\mathrm{NaTi}_{2} \mathrm{O}_{5} \mathrm{H}$. It is selective toward $\mathrm{Sr}$ and actinides, especially $\mathrm{Np}$ and $\mathrm{Pu}$. By treatment of the solid with peroxide by the Sandia group, the uptake of actinides was increased as was the uptake rate. The nature of this reaction is under investigation.

Another area of investigation we considered is the utilization of sodium micas as barriers to entrap Cs-137 and Sr-90 from leaking waste storage tanks. ${ }^{8,9,10}$ Potassium in micas, such as Biotite and phlogopite is strongly held and does not exchange over eons of geologic time. We have hydrothermally replaced $\mathrm{K}^{+}$by $\mathrm{Na}^{+}$, converting the inert mica into an ion exchanger. As such it has a high affinity for $\mathrm{Cs}^{+}$as well as $\mathrm{K}^{+}$. When about half the exchange sites are filled with these ions, the layers collapse, trapping the ions within. Brittle micas have a similar affinity for $\mathrm{Sr}^{2+}$ and may be used similarly.

\section{References}

1. Clearfield, A. Solid State Sci. 2001, 3, 103-112.

2. Clearfield, A.; Poojary, D. M.; Behrens, E. A.; Cahill, R. A.; Bortun, A. I.; Bortun, L. N. ACS Symp. Ser. 716, Bond, A. H.; Dietz, M. L.; Rogers, R. D. Eds.; American Chemical Society: Washington, D.C., 1999, pp.168-182. 
3. Tripathi, A.; Medvedev, D. G.; Nyman, M.; Clearfield, A. J. Solid State Chem. 2003, 175, 72-83.

4. Tripathi, A.; Medvedev, D.; Delgado, J.; Clearfield, A. J. Solid State Chem. 2004, 177, 2903-2915.

5. Behrens, E. A.; Sylvester, P; Clearfield, A. Environ. Sci. Tech. 1998, 32, 101-107.

6. Hobbs, D. T.; Nyman, M. D.; Clearfield, A. Tailoring Inorganic Sorbents for SRS Strontium and Actinide Separations: Optimized Monosodium Titanate and Pharmacosiderite Phase I Final Report, WSRC-TR-2004, Westinghouse Savannah River Co. Aiken, SC, 2004.

7. Medvedev, D.; Tripathi, A.; Clearfield, A.; Celestian, A.; Parise, J.; Hanson, J. Chem. Mater. 2004 16, 3659-3666.

8. Bortun, A. I.; Bortun, L. N.; Khainakov, S. A; Clearfield, A. Solv. Extra. Ion Exch. 1998, 16(4), 1067-1090.

9. Sylvester, P.; Clearfield, A. Nuclear Site Remediation, ACS Symp. Ser. 778, Eller, P.G.; Heineman, W. R. Eds., American Chemical Society: Washington, D.C., 2000, pp.133-145.

10. Sylvester, P.; Clearfield, A. Sep. Sci. and Tech. 1998, 33 (11), 1605-1615.

\section{Acknowledgement}

We gratefully acknowledge the U.S. Department of Energy Basic Energy Sciences, Grant No. DE-FG07-96ER14689 and DE-FG07-01ER63300, with funds supplied through Environmental Management. 


\section{Nanoporous Ti \& Zr Phosphate Getter Materials}

Glen E. Fryxell, Shas V. Mattigod, X. Shari Li, Dawn Wellman, Andy Felmy, Kevin Rosso

Pacific Northwest National Laboratory

Richland, WA 99354

\section{Email: glen.fryxell@pnl.gov}

Functional nanoporous materials have a number of advantages for getter material applications. Their high surface area provides the ability to sorb a large amount of the target analyte. The rigid open-pore structure allows for rapid diffusion and, hence, rapid sorption kinetics, improving their efficiency. The functional interface allows one to design very specific chemistry into the material to selectively sequester the targets of interest. The focus of our applied research is the design and synthesis of high-surface area, high-efficiency getter materials to selectively sequester radionuclides from spent nuclear fuel wasteforms in the proposed Yucca Mountain Repository. These targets include the actinides (particularly $\mathrm{Np}$ ), $\mathrm{Tc}$ (presumably as $\mathrm{TcO}_{4}{ }^{\mathrm{i}}$ ), and I (possibly either $\mathrm{I}_{\text {or }} \mathrm{IO}_{3}{ }^{2}$ ).

The actinide cations are known to have a high affinity for phosphate phases, making this a logical starting point for these getter materials (indeed, early $\mathrm{Pu}$ purification methods included co-precipitation with bismuth phosphate). Mesoporous $\mathrm{Ti}$ and $\mathrm{Zr}$ phosphate have been made [12], and mesoporous $\mathrm{TiPO}_{4}$ is reported to have anion exchange properties[1]. This suggests that within these nanoporous metal phosphate phases it is possible to tailor the interfacial Lewis acid sites in such a way to make these materials inherently bifunctional, i.e., to bind not only the actinide cations but also the pertechnetate and iodate anions as well.

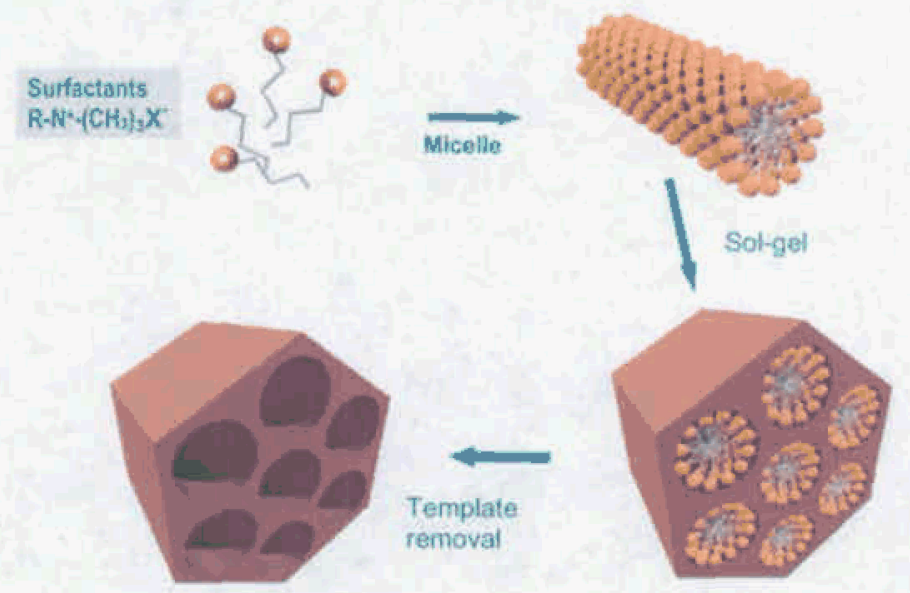

Figure 1. Schematic showing how surfactants and micelles can be used to create nanoporous materials.

The strategy adopted by the synthesis team is to use surfactant-templated syntheses to prepare inherently functional, nanoporous metal phosphates. This approach provides materials that are made up of nanoscale honeycombs, composed of arrays of uniformly sized pores. These pores are typically about $30 \AA$ in diameter. This morphology creates a huge amount of surface area in a very small volume. The surface areas of these materials are typically several hundred square meters per gram (as opposed to a few square meters per gram for the non-porous analogs). 
Surface area is important because it gives rise to binding capacity.

We started off by exploring the use of various different surfactants (CTAC, Tergitol P123, etc.) to see which was the most compatible with $\mathrm{Ti}$ and $\mathrm{Zr}$ chemistry, as well as to see what pore sizes were readily addressable. In addition, we have found that performing this synthesis using microwave heating of the reaction mixture speeds up the reaction time and improves the quality of the materials obtained. Various methods of removing the surfactant template have also been studied (calcination at various temperatures, Soxhlet extraction with refluxing ethanol, supercritical fluid extraction, acid washing, etc.). These methods generally produced materials with surface areas of $200-300 \mathrm{~m}^{2} / \mathrm{g}$, with pore diameters generally in the range of $30-40 \AA$. Calcination conditions were found to have an impact on both the surface area and the order of the pore structure.

The nanoporous $\mathrm{Ti}$ and $\mathrm{Zr}$ phosphate phases obtained from these efforts were then tested for actinide affinity, using $\mathrm{Pu}(\mathrm{IV})$ nitrate in $0.1 \mathrm{M} \mathrm{HNO}_{3}$ as an initial screening solution. Sorption kinetics was found to be facile, with equilibrium being achieved in less than an hour. Distribution coefficients ( $\mathrm{K}_{d}$, a mass-weighted partition coefficient) for $\mathrm{Pu}(\mathrm{IV})$ were typically several thousand and have been observed as high as 16,000. In practical terms for a solution/solids ratio of 100 (where these tests were performed), this indicates that these materials typically removed $>99 \%$ of the $\mathrm{Pu}(\mathrm{IV}$ ) from solution (initial concentration $2000 \mathrm{dpm} / \mathrm{mL}$ ). This is excellent actinide getter performance, especially under such acidic conditions.

Similar tests were carried out with these materials to find their affinity for $\mathrm{TcO}_{4}{ }^{-}$under both acidic and neutral conditions. These tests were negative with no pertechnetate binding being observed.

Modeling efforts have provided great insights into our understanding of the structure and mechanism of anion binding within these materials. These studies have allowed us to improve the design and synthesis of these nanoporous $\mathrm{Ti}$ and $\mathrm{Zr}$ phosphates, creating a material that we believe will bind both cations and anions by changing the speciation of the nanopore interface. Molecular modeling of this interface indicates that the binding of $\mathrm{TcO}_{4}{ }^{-}$is exothermic. Modification of the synthetic protocol to create these materials led to the preparation of a higher surface area Ti phosphate than we had previously prepared $\left(448 \mathrm{~m}^{2} / \mathrm{g}\right)$. Due to the presence of a displaceable chloride ligand in these materials, they are anticipated to have excellent binding affinity for pertechnetate anion as well as the actinide cations. Testing of this powerful new class of radionuclide getter materials is currently underway.

\section{Literature cited:}

1) "Mesoporous Titanium Phosphate Molecular Sieves with Ion- Exchange Capacity", Bhaumik, A.; Inagaki, S. J. Am. Chem. Soc. 2001, 123, 691-696.

2) "Highly Ordered Porous Zirconias from Surfactant-Controlled Syntheses: Zirconium OxideSulfate and Zirconium Oxo Phosphate", Ciesla, U.; Fröba, M.; Stucky, G.; Schüth, F. Chem. Mater. 1999, 11, 227-234. 


\section{A Porous Glass Getter for Long-Lived Radionuclides}

Werner Lutze, Pedro B. Macedo, and Weiliang Gong

Vitreous State Laboratory

The Catholic University of America

Washington, D.C. 20064

\section{Email: wernerl@vsl.cua.edu}

The performance assessment for the proposed Yucca Mountain HLW repository must provide "reasonable expectation" that radioactive materials can be disposed of without unreasonable risk to the health and safety of the public. Placing additional radionuclide barriers ("getter" materials) inside the repository supports the principle of reasonable expectation. A getter material would be needed if and when a waste package, particularly spent fuel, fails and releases long-lived radionuclides such as ${ }^{99} \mathrm{Tc},{ }^{129} \mathrm{I}$, and ${ }^{237} \mathrm{~Np}$ into water inside the repository. This event may not occur before thousands of years from now. Meanwhile the getter material will have been exposed for centuries to elevated temperatures and, depending on where it is placed, to radiation, moisture, and perhaps water. The atmosphere in the repository may have changed from oxidizing to reducing and back to oxidizing. A promising getter is one for which a convincing case can be made that its favorable properties are unlikely to deteriorate over geologic periods of time $\left(>10^{4} \mathrm{y}\right)$.

Porous high silica glass (PHSG) is a candidate material: relaxation is very slow in high silica glass at $200^{\circ} \mathrm{C}$, suggesting that pores will not anneal during the heat pulse in the repository. High silica glass is sufficiently corrosion resistant within the expected $\mathrm{pH}-\mathrm{Eh}$ range of the aqueous phase. $P H S G$ has a large, specific surface area, up to $1000 \mathrm{~m}^{2} / \mathrm{g}$. Its $\mathrm{SiO}_{2}$ content can be as high as $95 \mathrm{wt}-\%$. As far as the $\mathrm{SiO}_{2}$ content and the chemical durability are concerned, $P H S G$ can be compared with tektites, meteoritic impact glasses $\left(\mathrm{SiO}_{2}: 78-98 \mathrm{wt}-\%\right.$, age $\left.0.7 \mathrm{My}-35 \mathrm{My}\right)$, found on earth in various strewn fields. Pore surfaces in PHSG can adsorb negatively or positively charged species from aqueous solutions, depending on glass composition and pore treatment. Pores are typically $30 \mathrm{~nm}$ wide and connected. Nano-particles with various compositions can be generated within the pores to enhance capacity and selectivity for certain radionuclides.

How to make $P H S G$ ? First, a homogeneous alkali borosilicate glass is melted. Its composition is such that the melt undergoes spontaneous liquid-liquid phase separation (spinodal decomposition) when cooled below a certain temperature (Figure 1): 


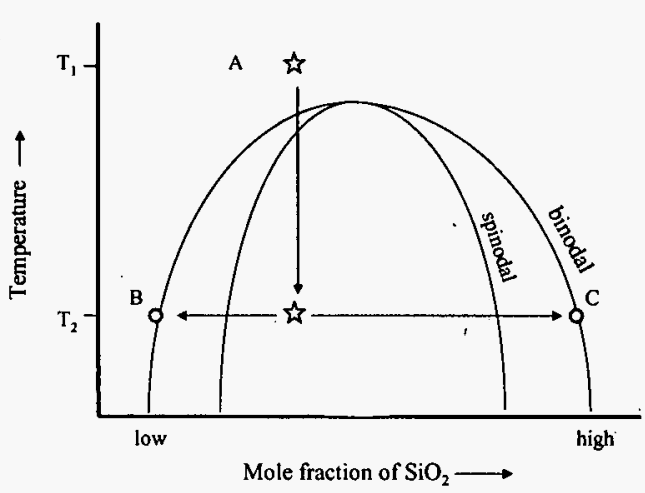

Figure 1. Spinodal Decomposition

A homogeneous alkali borosilicate glass melt of composition ' $A$ ' cools from temperature $T_{1}$ to $T_{2} . T_{2}$ is within the field of spinodal decomposition. If composition ' $A$ ' is held at $T_{2}$ two glasses of compositions, ' $B$ ' and ' $C$ ' will form. ' $C$ ' has a higher and ' $B$ ' a lower silica $\left(\mathrm{SiO}_{2}\right)$ concentration than ' $A$ '. ' $C$ ' has a much higher chemical durability than ' $B$ '. Leaching ' $B$ ' out of ' $\mathrm{C}$ ' leaves a $P H S G$ behind. Treatment of ' $\mathrm{B}$ ' can be controlled such that only alkali and boron are removed leaving chemically durable constituents as nano-particles in the pores. Depending on the composition of ' $A$,' these particles could be $\mathrm{ZrO}_{2}, \mathrm{SnO}_{2}, \mathrm{TiO}_{2}, \mathrm{Al}_{2} \mathrm{O}_{3}$, or others, in addition to $\mathrm{SiO}_{2}$. Particles can also be introduced by precipitating them inside the pores. Pore surfaces can be treated chemically to create surface sites that enhance anion selectivity. Positively charged sites are of $\mathrm{Si}-\mathrm{O}^{\cdots} \mathrm{M}^{\mathrm{n}+}$ type, where $\mathrm{M}$ can be $\mathrm{Al}, \mathrm{Zr}, \mathrm{Ag}, \mathrm{Tl}, \mathrm{Hg}, \mathrm{Pt}, \mathrm{Pd}$, and others. By varying the glass compositions ' $A$ ', ' $B$ ', and ' $C$ ' the getter capacity can be affected.

How well does $P H S G$ work? VSL has developed and patented PHSG materials in the 1980 s with customized selectivity for various cations, e.g. $\mathrm{Mn}, \mathrm{Sr}, \mathrm{I}$, and $\mathrm{Cs}$. The products are commercially available from Duratek, Inc. PHSG getters known as DURASIL TM(10) have been used in U.S. nuclear power plants to capture radionuclides from waste water. Several $P H S G$ were developed for iodine and showed satisfactory selectivity as long as iodine was not bonded to organic matter. Tc and Np have not yet been tested. At nuclear power plants columns filled with PHSG were operated at high flow rates, i.e., pores had to be fairly large and free of nano-particles. At Yucca Mountain the flow rates are small. Pores in the glass can be smaller and may contain nanoparticles.

Mechanisms of release of $\mathrm{Tc}, \mathrm{I}$, and $\mathrm{Np}$ from spent nuclear fuel suggest that all three elements are likely to be present as anions (iodide, pertechnetate, $\mathrm{Np}(\mathrm{V})$ carbonate complexes). Development of $P H S G$ getter materials for these species would focus on the following aspects:

- Starting with a glass, whose chemical durability can be evaluated based on a fairly solid understanding of the glass dissolution mechanism and a comparison with dissolution data from tektites or rhyolitic glass, work can focus on creating 'built-in' pore surface properties. 'Built-in' means that atoms ( $\mathrm{Al}, \mathrm{Ti}, \mathrm{Zr}$, Sn, etc.) introduced and substituting for silicon provide reactive surface sites without deteriorating the chemical and thermal durability of the porous glass matrix.

- Glass viscosity should be known to evaluate potential changes of pore sizes and at elevated temperatures.

- Immobilizing $\mathrm{I}^{(-)}$would be based on experience with introducing $\mathrm{Ag}^{(+)}$into the pores. 
- For Tc an attempt should be made to reduce $\mathrm{Tc}(\mathrm{VII})$ and immobilization as $\mathrm{Tc}(\mathrm{IV})$ oxyhydroxide within the pores.

- Np speciation in the pores may not be the same as outside. The water chemistry within the pores of the $P H S G$ is most likely affected by glass composition. Water chemistry and sorption of $\mathrm{Np}$ can also be affected by the composition of nano-particles in the pores. Information about pore water composition should be acquired. Retention of $\mathrm{Np}$ requires variation and testing of $P H S G$ compositions.

- Thermal effects on pore surface- and nano-particles properties must be determined.

- The mechanisms of retention of the nuclides of concern must be elucidated to determine potential conditions for their remobilization. 


\section{Metal Doped Carbonaceous Materials for Sequestration of Anionic Fission Products (Tc-99 and I-129)}

Steven M. Serkiz ${ }^{*}$, , 2, Daniel I. Kaplan ', C. Scott McWhorter ', Ragiay Zidan ', Tanju Karanfil $^{2}$, Jay S. Hoskins ${ }^{2}$, and Erin E. Cumbie ${ }^{2}$

${ }^{1}$ Savannah River National Laboratory, Aiken, SC 29808

${ }^{2}$ Clemson University Department of Environmental Engineering and Science, Anderson, SC 29625

Steven M. Serkiz

Savannah River National Laboratory

Building 773-A

Aiken, SC 29808

\section{Email: steven.serkiz@srs.gov}

Our research group has been conducting work on the production of transition and noble metal doped carbonaceous materials for application in the areas of environmental remediation, waste packaging, high-level waste separations, and hydrogen storage. Macroscale (e.g., metal doped activated carbons) as well as nanoscale (metal doped carbon nanotubes) materials have been produced and characterized over the past several years.

We report on the results of the production, characterization, and, reactivity of these materials for the separation and sequestration of anionic fission products ${ }^{129} \mathrm{I}^{-} / \mathrm{IO}_{3}{ }^{-}$and ${ }^{99} \mathrm{TcO}_{4}{ }^{-}$. In particular, the results of the following experiments are presented:

- production, modification, and characterization of silver impregnated activated carbons (SIAC);

- reactivity and stability of SIACs to ${ }^{129} \mathrm{I}^{-}$and ${ }^{99} \mathrm{TcO}_{4}{ }^{-}$anions;

- SIAC removal of ${ }^{129} \mathrm{I}$ and ${ }^{99} \mathrm{Tc}$ from an acidic high nitrate waste stream at the DOE's Savannah River Site; and

- production and characterization of $\mathrm{Fe}, \mathrm{Ag}, \mathrm{W}, \mathrm{Ti}$, and $\mathrm{Pt}$ doped carbon nanotubes.

The results of this research show that silver doped carbonaceous materials are promising as anionic fission product getters. In particular, the SIACs iodine sequestration mechanism is thought to be formation of an AgI surface precipitate. Silver leaching of these materials has shown to be low when the silver in the activated carbon is in the $\mathrm{AgCl}(\mathrm{s})$ form. The SIACs also have high capacities for removing Tc in the pertechnetate form and the reaction mechanism is thought to be reduction to an insoluble $\mathrm{Tc}(\mathrm{IV}) \mathrm{O}_{2}$ (s) form. This chemistry has been extended to the nanoscale by the production of metal doped carbon nanotubes (MD-CNTs). A chemical vapor deposition technique was used to produce MD-CNTs with a range of metal dopants, sizes, and location of the metal dopant. These materials have been characterized, and their reactivity is being evaluated. 
Workshop on Development of Radionuclide Getters for the Yucca Mountain Waste Repository

November 18-19, 2004

SECTION IV:

GeTter DURABILITY

Page 39 of 55 


\section{Radiolytic Stability of Radionuclide Getters}

William J. Weber

Pacific Northwest National Laboratory

Richland, Washington

\section{Email: bill.weber@pnl.gov}

\section{Summarized by Wayne Lukens}

Radionuclide getters for use in a high-level waste repository will be exposed to high levels of radiation from the decay of fission products in spent fuel as well as the decay of the sequestered radionuclide. Therefore, any functional getter must be sufficiently stable toward radiolysis to continue to function after receiving very high doses of radiation. The purpose of this presentation is to summarize what is known about radiation effects in potential getter materials and to discuss the potential for testing the radiolytic stability of getter materials.

In the past the general focus of radiolytic stability of materials associated with nuclear waste repositories has been on the stability of the waste form. With the exception of porous glasses, the radiolytic stability of potential radionuclide getters has been largely unexplored. Consequently, little is known about the effect of radiation on such materials. However, typical radiolytic changes produced in solid materials include formation of defects, formation of surface hydroxyl groups (in wet environments), dehydration of surfaces (in dry environments), and breaking of covalent and ionic bonds. All of these effects could change the affinity and capacity of getter materials toward the target radionuclide.

Due to the uncertainty of the effect of radiolytic changes on the actual performance of getter materials, it is difficult if not impossible to predict the radiolytic stability of potential getters. Therefore, the radiation exposure that a getter would experience must be simulated to determine whether the getter possesses sufficient radiolytic stability.

The most realistic simulation is $\gamma$-irradiation by ${ }^{60} \mathrm{Co}$. This is a bulk technique that is well suited to irradiating moderately-sized samples that can later be tested to determine the effect of a given dose upon the affinity and sorption capacity of the getter. ${ }^{60} \mathrm{Co}$ irradiation is a good simulation for the field generated by the decay of fission products as well as that generated by the decay of ${ }^{127} \mathrm{I}$ and ${ }^{99} \mathrm{Tc}$ trapped in the getter; it is a less realistic simulation of the radiolytic effects of the $\alpha$ particle and recoil nucleus of ${ }^{237} \mathrm{~Np}$ decay. Simulation using ${ }^{60} \mathrm{Co}$ irradiation is also somewhat limited by the comparatively low dose rate of such irradiators. Realistic simulations of the dose received over the lifetime of the getter would be time consuming but are possible.

Other methods of irradiation could shorten experiment times or provide more realistic simulation of the damage caused by $\alpha$-particles or recoil nuclei. These techniques include $\mathrm{X}$-ray irradiation with synchrotron sources, electron irradiation in electron microscopes, and irradiation with energetic ions using cyclotrons. In all cases much higher dose rates are possible, but sample sizes are very small. Therefore, these techniques could be used to study the structural stability of getter materials but might not be useful for determining the effect of radiation upon getter 
performance. In addition to irradiation, the changes that radiation produces in materials are often analogous to those produced by hydrothermal conditions. Consequently, the stability of getters toward hydrothermal conditions might be a good predictor of the radiolytic stability of the materials.

An additional problem with testing the radiolytic stability of getters is that the dose that they would receive is not currently known. As a first step in determining the radiolytic stability of getters, the dose rate to a getter placed in the invert and a getter placed inside a container would have to be determined.

In summary, the ionization processes and other changes produced by radiation are poorly understood in most materials. This is especially true of getter materials, which have received little attention. In addition, the dose that getter materials would receive is currently unknown. Once the dose is known, however, it should be possible to realistically simulate the dose that the getter would receive over its lifetime using existing techniques, especially ${ }^{60} \mathrm{Co}$ irradiation. 


\section{Geochemical Stability}

Susan Brantley

Penn State University

2217 Earth \& Engineering Sciences

University Park, PA 16802

Email: brantley@essc.psu.edu

\section{Summarized by Yifeng Wang}

Long-term stability under anticipated repository conditions is an important attribute for the performance assessment of getter materials. In the Yucca Mountain repository environments a getter material to be emplaced in the invert of waste drift will be subjected to high-temperature regimes, aqueous dissolution, and high radiation fields. In such environments little is known about the stability of candidate getter materials, especially nanoporous materials, which have been developed only recently in the laboratory. Potential radiation damage of nanoporous structures in the materials is an issue of particular interest if the sorption capability of the materials depends on specific nanometer-scale surface structures. For other materials radiation may only decrease material crystallinity by partially damaging crystal structures, which may even lead to an increase in the specific surface area of the materials. In this aspect the material sorption capability may not be significantly, at least not detrimentally, affected by radiation damage. The durability of getter materials subjected to aqueous dissolution can be evaluated by the measurements of dissolution rates of these materials under relevant chemical conditions using flow-through reactors. Related data on the dissolution of natural minerals can be useful for understanding of long-term behavior of engineered materials. Layered double hydroxides have been found to form in natural systems. Apatite and zirconium minerals have been found stable on a geological time scale. 


\section{SECTION V:}

\section{Thermodynamics \& Modeling}




\section{Technetium Thermodynamics and Speciation}

Joseph A. Rard

Energy and Environment Directorate

Lawrence Livermore National Laboratory

University of California

Livermore, California 94550

Email: rard1@1lnl.gov

The prediction of the chemical forms (speciation) and concentrations of an element present in solution, and the variation of its solubilities as a function of $\mathrm{pH}$, redox potential, and concentration of other ions can best be made using thermodynamic modeling codes, which in turn require a reliable and critically assessed thermodynamic data base.

Rard et al. ${ }^{1}$ critically reviewed available thermodynamic data for technetium, its inorganic compounds, and aqueous species as part of the Nuclear Energy Agency series of reviews of thermodynamic data for elements of special importance for radioactive waster management. Literature coverage is through 1998. Few studies of the thermodynamic properties of technetium have been published since then, the most notable being the extensive solubility measurements of Hess et al. ${ }^{2}$ for $\mathrm{TcO}_{2} \cdot x \mathrm{H}_{2} \mathrm{O}(\mathrm{am})$ in chloride solutions. Neck et al. ${ }^{3}$ have modeled the solubilities and speciation of technetium in aqueous solutions.

The thermal neutron fission of ${ }^{235} \mathrm{U}$ and ${ }^{239} \mathrm{Pu}$ produces ${ }^{99} \mathrm{Tc}$ in about $6 \%$ yield and results in significant amounts of technetium in spent nuclear reactor fuel and reprocessing solutions. Under oxidizing conditions technetium exists predominantly as the pertechnetate ion $\mathrm{TcO}_{4}^{-}$. However, the aqueous solubilities of pertechnetate salts are too large for them to become solubility limiting phases under normal environmental conditions.

Under reducing conditions $\mathrm{TcO}_{2} \cdot x \mathrm{H}_{2} \mathrm{O}(\mathrm{am})$ becomes the solubility limiting phase, along with possibly $\mathrm{TcO}_{2}$ (cr). Aqueous solutions in equilibrium with these solid phases consist of various hydrolyzed forms of Tc(IV) along with various complexes when other ions are present. Various aqueous species and inorganic complexes of $\mathrm{Tc}(\mathrm{VI})$ and $\mathrm{Tc}(\mathrm{V})$ have been identified, but they are thermodynamically unstable. Tc(III) had been identified under very reducing conditions, but it is not likely to be significant under environmental conditions.

\section{References}

(1) Rard, J. A.; Rand, M. H.; Anderegg, G.; Wanner, H. Chemical Thermodynamics of Technetium, edited by M. C. A. Sandino and E. Östhols, Chemical Thermodynamics Vol. 3, North-Holland/Elsevier Science B. V.: Amsterdam, 1999, 568 pages.

(2) Hess, N. J.; Xia, Y.; Rai, D.; Conradson, S. D. Thermodynamic Model for the Solubility of $\mathrm{TcO}_{2} \cdot x \mathrm{H}_{2} \mathrm{O}(\mathrm{am})$ in the Aqueous $\mathrm{Tc}(\mathrm{IV})-\mathrm{Na}^{+}-\mathrm{Cl}^{-}-\mathrm{H}^{+}-\mathrm{OH}^{-}-\mathrm{H}_{2} \mathrm{O}$ System. J. Solution Chem. 2004, 33, 199-226. 
(3) Neck, V.; Fanghänel, T.; Kim, J. I. Thermodynamische Modellierung von Technetium in natürlichen aquatischen Systemem. Report FZKA 6340, Forschungszentrum Karlsruhe GmbK, Karlsruhe, July 1999.

\section{Acknowledgement}

This work was performed under the auspices of the U. S. Department by University of California, Lawrence Livermore National Laboratory, under contract No. W-7405-ENG-48. 


\section{ACKNOWLEDGEMENTS}

Sandia is a multiprogram laboratory operated by Sandia Corporation, a Lockheed Martin Company, for the United States Department of Energy's National Nuclear Security Administration under contract DE-AC04-94AL85000.

This report was prepared by Sandia National Laboratories pursuant to a contract funded by the United States Department of Energy (DOE), Office of Civilian Radioactive Waste Management (OCRWM), Office of Science and Technology and International (OST\&I), and neither Sandia National Laboratories nor any of its contractors or subcontractors nor the DOE/OCRWM/OST\&I, nor any person acting on behalf of either:

Makes any warranty or representation, express or implied, with respect to the accuracy, completeness, or usefulness of the information contained in this report, or that the use of any information, apparatus, method, or process disclosed in this report may not infringe privatelyowned rights; or

Assumes any liabilities with respect to the use of, or for damages resulting from the use of, any information, apparatus, method, or process disclosed in this report. Reference herein to any specific commercial product, process, or service by trade name, trademark, manufacturer, or otherwise, does not necessarily constitute or imply its endorsement, recommendation, or favoring by DOE/OCRWM/OST\&I.

The views and opinions of authors expressed herein do not necessarily state or reflect those of the DOE/OCRWM/OST\&I. 


\section{APPENDICES}

Page 47 of 55 


\section{A. Conference Attendee List}

\section{Sponsors:}

Mark Peters

Drew Tait

Bob Budnitz

Lester Morss

\section{Organizers:}

Robert Moore

Wayne Lukens

Speakers:

John Wengle

Peter Swift

Patrick Brady

Ken Nash

J. Clara Wren

Brian Viani

Baohua Gu

Abraham Clearfield

Glen Fryxell

William Weber

Susan Brantley

Bernd Grambow

Joseph Rard

Eric Sonnenthal

Steven Serkiz

Werner Lutze

Shas Mattigod

Yifeng Wang

Others:

Hong-Nian Jow

Shas Mattigod

Rod Ewing

Dean Peterman

Jim Jerden (Argonne)

Weilang Gong (Catholic University)

Bob Finch (Argonne)
(301) 903-3947

(301) 9039311

(505) 844-1281

(510) 486-4305

(202) 586-0396

(505) $284-4817$

(505) 844-7146

(509) 335-2654

(519) 661-2166 x 86339

(925) 423-2001

(865)-574-7286

(979) 845-2936

(509) $375-3856$

(509) $376-3644$

(814) 865-1619

(925) 422-6872

(510) 486-5866

(803) 725-5422

(509) 3764311

(505) 844-8271

(505) 284-4819

(509) 3764311

(734) 6478529

(208) 533-4104
Mark.Peters@hq.doe.gov

Drew.Tait@science.doe.gov

Robert.Budnitz@rw.doe.gov

lester.morss@science.doe.gov

rcmoore@sandia.gov

wwlukens@lbl.gov

john.wengle@rw.doe.gov

pnswift@sandia.gov

pvbrady@sandia.gov

knash@wsu.edu

jcwren@uwo.ca

viani1@llnl.gov

gub1@ornl.gov

clearfield@mail.chem.tamu.edu

glen.fryxell@pnl.gov .

bill.weber@pnl.gov

brantley@essc.psu.edu

Bernd.Grambow@subatech.in2p3.fr

rard1@1lnl.gov

ELSonnenthal@lbl.gov

steven.serkiz@srs.gov

wernerl@vsl.cua.edu

shas.mattigod@pnl.gov

ywang@sandia.gov

hjow@sandia.gov.

shas.mattigod@pnl.gov

rodewing@umich.edu

petedr2@inel.gov 


\section{B. WORKSHOP AGENDA}

\section{Workshop on Development of Radionuclide Getters for}

the Yucca Mountain Waste Repository

November 18\&19, 2004

Agenda

Doubletree Rockville

1750 Rockville Pike

Rockville, MD 20852

Phone: 301-486-1100

Fax: 301-486-0163

\begin{tabular}{|c|c|c|}
\hline & Wednesday, November 17, 2004 & \\
\hline $6: 00-8: 00 \mathrm{pm}$ & $\begin{array}{c}\text { Buffet Dinner at } \\
\text { Rockville Doubletree }\end{array}$ & \\
\hline
\end{tabular}

\begin{tabular}{|c|c|c|}
\hline & Thursday, November 18, 2004 & Speaker \\
\hline $8: 00 \mathrm{am}$ & Introduction to Workshop / Sponsor Comments & John Wengle \\
\hline $8: 15 \mathrm{am}$ & Yucca Mountain Performance Assessment & Peter Swift \\
\hline $8: 45 \mathrm{am}$ & Yucca Mountain Source Term & Pat Brady \\
\hline $9: 30 \mathrm{am}$ & In-Drift Chemistry & Pat Brady \\
\hline $10: 15 \mathrm{am}$ & In-Drift Flow & Eric Sonnenthal \\
\hline $11: 00 \mathrm{am}$ & Break & \\
\hline & Session I: Traditional Getter Materials & \\
\hline $11: 15 \mathrm{am}$ & Getters for Neptunium / Neptunium sorption & Ken Nash \\
\hline $12: 00 \mathrm{pm}$ & $\begin{array}{c}\text { Lunch Break } \\
\text { Provided by Bethesda Marriott }\end{array}$ \\
\hline $1: 30 \mathrm{pm}$ & Getters for Iodide / Iodine Chemistry & J. Clara Wren \\
\hline
\end{tabular}




\begin{tabular}{|c|c|c|}
\hline & Thursday, November 18, 2004 & Speaker \\
\hline $2: 15 \mathrm{pm}$ & Traditional Getters for Technetium & Brian Viani \\
\hline $3: 00 \mathrm{pm}$ & Ion Exchange Getters for Technetium & Baohua Gu \\
\hline $3: 45 \mathrm{pm}$ & Session I discussion & \\
\hline $5: 00 \mathrm{pm}$ & Dinner & \\
\hline
\end{tabular}

\begin{tabular}{|c|c|c|}
\hline & Friday, November 19, 2004 & Speaker \\
\hline $8: 00 \mathrm{am}$ & Session II: Nanoporous Materials & \\
\hline $8: 40 \mathrm{am}$ & Microporous Materials & Abraham Clearfield \\
\hline $9: 20 \mathrm{am}$ & Mesoporous Materials & Glen Fryxell \\
\hline $9: 40 \mathrm{am}$ & Porous Glasses & Werner Lutze \\
\hline $10: 00 \mathrm{am}$ & Carbon Nanotube Materials & Steven Serkiz \\
\hline $10: 30 \mathrm{am}$ & Session II discussion & \\
\hline & Break & \\
\hline $10: 45 \mathrm{am}$ & Session III: Durability & \\
\hline $11: 25 \mathrm{am}$ & Radiolytic Stability & Bill Weber \\
\hline $12: 05 \mathrm{pm}$ & Geochemical Stability & Susan Brantley \\
\hline $1: 00 \mathrm{pm}$ & Lunch Break & Bernd Grambow \\
\hline $1: 40 \mathrm{pm}$ & Provided by Bethesda Marriott & \\
\hline $2: 10 \mathrm{pm}$ & Material Durability & \\
\hline & Session III discussion & \\
\hline & Break & \\
\hline & & \\
\hline
\end{tabular}




\begin{tabular}{|c|r|c|}
\hline & Friday, November 19, 2004 & Speaker \\
\hline & Session IV: Thermodynamics and Modeling & \\
\hline $2: 25 \mathrm{pm}$ & Technetium Thermodynamics and Speciation & Joseph Rard \\
\hline $3: 05 \mathrm{pm}$ & Neptunium Thermodynamics and Speciation & Dhanpat Rai \\
\hline $3: 45 \mathrm{pm}$ & Session IV discussion & \\
\hline $4: 15 \mathrm{pm}$ & Discussion of topic importance and ranking & \\
\hline $5: 00 \mathrm{pm}$ & Adjourn & \\
\hline
\end{tabular}




\section{List of Publications Related to Radiation Effects on Potential "GETTER" MATERIALS}

1. M. Cameron, L.M. Wang, K.D. Crowley and R.C. Ewing, HRTEM observation on electron irradiation damage in F-apatite, Proceedings of the 50th Annual Meeting of the Electron Microscopy Society of America, Edited by G.W. Bailey and J.A. Small (San Francisco Press, 1992) 378-379.

2. A. Meldrum, L.M. Wang, Y.X. Guo and R.C. Ewing, Electron irradiation-induced phase segregation in crystalline and amorphous fluorapatite, American Mineralogist 82 (1997) 858-869.

3. L.M. Wang, S.X. Wang, W.L. Gong and R.C. Ewing, Temperature dependence of Kr ioninduced amorphization of mica minerals, Nuclear Instruments and Methods in Physics Research B 141 (1998) 501-508.

4. B.X. Gu, L.M. Wang and R.C. Ewing, The effect of amorphization on the Cs ion exchange and retention capacity of zeolite-NaY, J. Nuclear Materials 278 (2000) 64-72.

5. S.X. Wang, L.M. Wang and R.C. Ewing, Electron and ion irradiation of zeolites, J. Nuclear Materials (2000) 233-241.

6. B.X. Gu, L.M. Wang, S.X. Wang, D.G. Zhao, V.H. Rotberg and R.C. Ewing, The effect of $\mathrm{H}^{+}$irradiation on the Cs ion exchange capacity of zeolite-NaY, J. Materials Chemistry 10 (2000) 2610-2616.

7. M. Nyman, B.X. Gu, L.M. Wang, R.C. Ewing and T.M. Neoff, Synthesis and characterization of a new microporous cesium silicotitanate (SNL-B) molecular sieve, Microporous Materials 40 (2000) 115-125.

8. M. Nyman, F. Bonhomme, D.M. Teter, R.S. Maxwell, B.X. Gu, L.M. Wang, R.C. Ewing and T.M. Neoff, Integrated experimental and computational methods for structure determination and characterization of a new, highly stable cesium silicotitanate phase, $\mathrm{Cs}_{2} \mathrm{TiSi}_{6} \mathrm{O}_{15}$ (SNL-A), Chemistry of Materials 12 (2000) 3449-3458.

9. Binxi Gu, Lumin Wang, P.A. Simpson, L.D. Minc and R.C. Ewing, Radiation and thermal effects in zeolite-NaY. Materials Research Society Symposia Proceedings 608 (2000) 493-498.

10. B.X. Gu, L.M. Wang, L.D. Minc and R.C. Ewing, Temperature effects on the radiation stability and ion exchange capacity of smectites, J. Nuclear Materials 297 (3) (2001) 345354.

11. B.X. Gu, L.M. Wang, S.X. Wang and R.C. Ewing, Radiation effects on materials in the near-field of a nuclear waste repository, SCIENTIFIC BASIS FOR NUCLEAR WASTE MANAGEMENT XXIV, Materials Research Society Symposia Proceedings 663 (2001) 883-891.

12. Binxi Gu, Lumin Wang, Shixin Wang, Donggao Zhao, Victor H. Rotberg, R.C. Ewing, Effects of proton irradiation in zeolite-Y, Materials Research Society Symposia Proceedings 650 (2001) R3.16.1-6. 


\section{DisTRIBUTION LiST}

$1 \quad$ US Department of Energy

Office of Science \& Technology \& International

Attn: John Wengle, RW-40

1000 Independence Ave., S.W

Washington, DC 20585

1 Idaho National Laboratory

Attn: Dean Peterman, 7113

P.O. Box 1625

Idaho Falls, ID 83415-7113

3 Lawrence Berkeley National Laboratories

Attn: Wayne Lukens, 70A1150 (2)

Eric Sonnenthal, 90R1116

1 Cyclotron Road Mail Stop 70A-1150

Berkeley, CA 94720-1150

2 Lawrence Livermore National Laboratory

Attn: Brian Viani

Jospeh Rard

7000 East Avenue

Livermore, CA 94550

1 Oak Ridge National Laboratory

Attn: Baohua Gu

PO Box 2008 MS6036

Oak Ridge, TN 37831-6036

3 Pacific Northwest National Laboratory

Attn: Glen Fryxell, K2-44

Bill Weber, K8-93

Shas Mattigod, K6-81

P.O. Box 999

Richland, WA 99352

1 Pennsylvania State University

Attn: Susan Brantley

2217 Earth \& Engineering Sciences

University Park, PA 16802

1 Savannah River Site

Attn: Steven Serkiz

Aiken, SC 29808 


\section{DISTRIBUTION LIST (CONTINUED)}

1 Texas A\&M University

Attn: Abraham Clearfield, MS 3255

College Station, TX 77843

1 The Catholic University of America

Attn: Werner Lutze

620 Michigan Ave., N.E.

Washington, DC 20064

1 University of Michigan

Attn: Rod Ewing

Geological Sciences

1100 N. University

Ann Arbor, MI 48109-1005

1 University of Western Ontario

Attn: J. Clara Wren

1151 Richmond Street, Suite 2,

London, Ontario, Canada, N6A 5B8

1 Washington State University

Attn: Ken Nash

Department of Chemistry

Pullman, WA 99164-4630

1. MS 0754 Patrick Brady, 6118

$1 \quad$ MS $0779 \quad$ Hong-Nian Jow, 6875

1.MS 0778 Peter Swift, 6851

2 MS 1136 . Robert Moore, 6872

1 MS 0772 Yifeng Wang, 6852

1 MS 0779 Kathleen C. Holt, 6874

2 MS 9018 Central Technical Files, 8945-1

2 MS 0899 Technical Library, 4536 


\subsection{Sandia National Laboratories}

Page 55 of 55 